\title{
Dua Puluh Tahun Riset Perpajakan dalam Akuntansi: Suatu Studi Bibliografi
}

\author{
Nurul Herawati ${ }^{*}$, Bandi Bandi ${ }^{2}$ \\ ${ }^{1}$ Fakultas Ekonomi dan Bisnis Universitas Trunojoyo Madura / PDIE Universitas Sebelas Maret \\ 2 Fakultas Ekonomi dan Bisnis Universitas Sebelas Maret \\ *Penulis korespondensi; Email: herawati@trunojoyo.ac.id
}

\begin{abstract}
ABSTRAK
Penelitian ini bertujuan meninjau perkembangan penelitian perpajakan dalam akuntansi di Indonesia selama 20 tahun. Tinjauan penelitian didasarkan pada 83 artikel perpajakan di 7 jurnal terakreditasi nasional dengan periode amatan 1997-2016. Pendekatan pertama, pemetaan area mencakup seleksi artikel; klasifikasi artikel berdasarkan topik, metode dan disiplin ilmu; karakteristik jurnal; dan karakteristik artikel. Penelitian ini juga memisahkan periode 20 tahun ke dalam dua dekade. Pendekatan kedua, analisis komunitas ilmuwan perpajakan di area akuntansi melalui jumlah sitasi di Google Scholar. Pemetaan area menunjukkan market share artikel perpajakan sebesar $17 \%$ dari penelitian akuntansi, journal share artikel perpajakan mengalami peningkatan selama dua dekade dan journal share tertinggi ada di Jurnal Akuntansi dan Keuangan dan EKUITAS Jurnal Ekonomi dan Keuangan. Topik penelitian perpajakan berkisar pada akuntansi keuangan, keperilakuan, dan evaluasi kebijakan. Metode penelitian kuantitatif merupakan yang dominan dalam penelitian perpajakan. Metode archival, survei dan kajian pustaka merupakan tiga metode penelitian yang paling dominan. Semua jurnal didominasi oleh disiplin sumber ekonomi. Analisis sitasi menunjukkan terdapat 49\% artikel yang mendapatkan jumlah sitasi antara 41 sampai 1. Jurnal yang paling banyak mendapatkan sitasi adalah Jurnal Akuntansi dan Keuangan. Analisi sitasi menunjukkan hampir setengah penelitian perpajakan sudah memiliki kontribusi bagi ilmu perpajakan dalam akuntansi.
\end{abstract}

Kata kunci: Akuntansi; penelitian perpajakan; studi bibliografi.

\begin{abstract}
This study aims to review the development of tax studies in accounting in Indonesia for 20 years. The research review is based on 83 tax articles in 7 national accredited journals over the 1997-2016 observation period. The first approach is started with the charting of the field includes article selection; classification of articles by topic, method and discipline; the characteristics of the journal; and characteristics of the article. The study also separates the 20-year period into two decades. The second approach is the analysis of the tax-scholar community in the accounting area through citations in Google Scholar. Charting the field shows market share of tax article is $17 \%$ of accounting research, the journal share of taxation articles has increased for two decades and the highest journal share is in Jurnal Akuntansi dan Keuangan and EKUITAS Jurnal Ekonomi dan Keuangan. Taxation research topics vary from financial accounting, behavioral, and policy evaluation. Quantitative research method is the dominant method. Archival, survey and literature review are the three most dominant research methods. All journals are dominated by the discipline of economic resources. The result of citation analysis shows that 49\% articles get citations. The most cited journal is Jurnal Akuntansi dan Keuangan. The citation analysis shows that almost half of the tax studies have already the contribution to the taxation science in accounting.
\end{abstract}

Keywords: Accounting; bibliographic study; tax research.

\section{PENDAHULUAN}

Penelitian akuntansi tidak hanya berkaitan dengan akuntansi keuangan, akuntansi manajemen, akuntansi biaya, akuntansi sektor publik, akuntansi syariah, sistem informasi akuntansi, auditing, pendidikan akuntansi namun juga mencakup perpajakan. Shackelford and Shevlin (2001) menyatakan penelitian pajak memiliki sejarah panjang di banyak disiplin ilmu. Sifat multidisiplin 
penelitian pajak inilah yang membuat penelitian pajak menarik, namun sulit. Penelitian pajak bisa jadi sulit tidak hanya karena kita harus mengikuti studi pajak di bidang akuntansi, keuangan, ekonomi, dan hukum, namun juga karena berbagai disiplin ilmu sering menggunakan bahasa yang berbeda dan memiliki perspektif yang berbeda (Hanlon and Heitzman 2010). Beberapa studi (seperti Shackelford and Shevlin 2001, Maydew 2001, Hanlon and Heitzman 2010, dan Graham 2011) telah melakukan tinjauan penelitian pajak dalam akuntansi serta penelitian pajak di bidang ekonomi dan keuangan sejauh hal itu berkaitan dengan atau dipengaruhi oleh penelitian akuntansi.

Beberapa penelitian (seperti Dyckman \& Zeff 1984, Brown \& Gardner 1985, Bonner et al. 2006, Chan et al. 2009, Oler et al. 2010, Coyne et al. 2010, Dunbar \& Weber 2014) telah memotret perkembangan riset akuntansi melalui hasil-hasil penelitian yang dipublikasi di jurnal akuntansi internasional terbaik untuk melihat topik, metodologi, besarnya kontribusi penelitian akuntansi melalui sitasi, jurnal yang paling berpengaruh dalam akuntansi. Begitu juga telah ada beberapa penelitian yang memotret perkembangan riset perpajakan sebagai subarea akuntansi melalui hasil-hasil penelitian yang dipublikasi di jurnal-jurnal internasional baik jurnal akuntansi internasional terbaik (Al Irsyad dan Martani 2013) dan jurnal perpajakan internasional terbaik (seperti Adhikari et al. (2002) di Journal of International Accounting Auditing \& Taxation antara tahun 1992 and 2001; Dykxhoorn and Sinning (2010) di Journal of International Accounting Auditing \& Taxation untuk tahun 2002-2010; Hutchison and White (2003) di Journal of the American Taxation Association 1979-2000).

Secara umum, hasil penelitian potret perkembangan riset akuntansi dan riset perpajakan sebagai subarea akuntansi-melalui hasil-hasil penelitian yang dipublikasi di jurnal internasional terbaik (jurnal akuntansi internasional dan jurnal perpajakan internasional) seperti tersebut di atas menunjukkan tingkat proporsi paper perpajakan selalu di bawah proporsi paper akuntansi keuangan, akuntansi manajerial, dan audit; dan metodologi archival/empirical digunakan dalam sebagian besar riset perpajakan. Bagaimana dengan perkembangan riset perpajakan sebagai subarea akuntansi di Indonesia jika dilihat dari publikasi di jurnal-jurnalnya? Sebatas pengetahuan peneliti, potret perkembangan penelitian perpajakan belum ditemukan. Analisis yang berfokus pada salah satu topik merupakan hal penting di dalam mengevaluasi kinerja akademisi akuntansi (Bonner et al. 2006). Hal inilah salah satu yang memotivasi peneliti untuk melihat sejarah perkembangan penelitian perpajakan sebagai suatu subarea akuntansi di Indonesia.
Di Indonesia, penelitian perpajakan sebagai suatu sub area dalam akuntansi telah nampak pada 2 jurnal yang saat ini menjadi jurnal akreditasi nasional yaitu EKUITAS Jurnal Ekonomi dan Keuangan sejak tahun 1997 dan Jurnal Akuntansi dan Keuangan sejak tahun 1999. Namun dalam ajang bergengsi bagi para Akuntan Indonesia untuk memaparkan berbagai hasil penelitian akuntansi terbaik dan diselenggarakan setiap tahun sejak tahun 1997 (yang dikenal dengan nama Simposium Nasional Akuntansi (SNA)), penelitian perpajakan sebagai suatu subarea akuntansi baru mulai mendapatkan "pengakuan" sejak SNA ke 9 yaitu tahun 2006. SNA ke 9 tersebut memasukkan kajian bidang perpajakan bergabung dengan bidang kajian akuntansi sektor publik. SNA ke 16 tahun 2013 baru memberikan tempat sendiri sebagai kajian bidang perpajakan sebagai bidang kajian subarea akuntansi. Disamping itu, muncul beberapa jurnal-jurnal akuntansi periode di atas tahun 2000-an dan berjalannya waktu jurnal-jurnal tersebut terakreditasi seperti Jurnal Akuntansi dan Auditing Indonesia terbit perdana tahun 2002, Jurnal Akuntansi Keuangan Indonesia terbit perdana pada tahun 2004, Jurnal Akuntansi terbit perdana tahun 2004, Jurnal Akuntansi Multiparadigma terbit perdana pada tahun 2010, dan Journal of Economics, Business, \& Accountancy VENTURA terbit perdana tahun 2010. Namun hanya terdapat 3 (tiga) jurnal akreditasi yang secara spesifik menyebutkan kajian bidang perpajakan dengan bertambahnya jurnal Akuntansi pada tahun 2004. Fenomena yang ada di Indonesia tersebut juga memotivasi peneliti untuk melihat sejarah perkembangan penelitian perpajakan sebagai suatu subarea akuntansi di Indonesia dalam bentuk bibliografi selama periode 20 tahun.

Penelitian ini mengacu pada kerangka penelitian Hesford et al. (2007) tentang bibliografi penelitian di bidang akuntansi manajemen berdasarkan 916 artikel akuntansi manajemen dalam 10 jurnal. Hesford et al. (2007) menggunakan dua pendekatan yaitu pemetaan area (charting the field) dan analisis komunitas (analyzing the community). Pendekatan pertama, pemetaan area dilakukan dengan menunjukkan "pangsa pasar" (market share) akuntansi manajemen sebagai suatu subarea dalam akuntansi dan juga menunjukkan "bagian jurnal" (journal share) dari masingmasing jurnal yang menjadi sampel penelitian dalam hal jumlah artikel akuntansi manajemen yang mereka publikasikan. Pemetaan area mencakup seleksi artikel; klasifikasi artikel berdasarkan topik, metode dan disiplin ilmu; karakteristik jurnal; karakteristik artikel dan karakteristik penulis. Pendekatan kedua, analisis komunitas 
yaitu analisis komunitas ilmuwan akuntansi manajemen. Analisis komunitas yang digunakan mencakup analisis sitasi dan ukuran jaringan sosial (menggunakan beberapa ukuran jaringan sosial yang mengungkapkan hubungan antara, dan pengaruh, individu dalam penelitian akuntansi manajemen). Studi Hesford et al. (2007) melakukan pengamatan selama periode 20 tahun, dan juga membagi menjadi beberapa dekade untuk menunjukkan perubahan dari waktu ke waktu.

Penelitian ini mencoba mengkaji dengan pendekatan yang dilakukan Hesford et al. (2007) tersebut namun dikaitkan dengan hasil penelitian perpajakan dalam akuntansi di Indonesia. Tinjauan kondisi penelitian perpajakan dalam akuntansi di Indonesia dilakukan dengan menggunakan 83 artikel perpajakan (lampiran tabel 8) yang dipublikasi dalam 7 (tujuh) jurnal terakreditasi nasional (tabel 1) yang tersedia secara online selama periode 20 tahun (1997-2016). Tinjauan dibatasi hanya pada jurnal di kalangan peneliti akuntansi saja. Bagian pertama, studi ini memetakan area penelitian perpajakan dalam akuntansi dengan menunjukkan "pangsa pasar" (market share) perpajakan sebagai subarea dalam akuntansi, dan juga "bagian jurnal" (journal share) dari masingmasing dari 7 jurnal dalam hal jumlah artikel perpajakan yang mereka publikasikan. Pemetaan area yang dilakukan dalam penelitian ini mencakup seleksi artikel; klasifikasi artikel berdasarkan topik, metode dan disiplin ilmu; karakteristik jurnal; dan karakteristik artikel. Penelitian ini juga melakukan pengamatan selama periode 20 tahun (1997-2016), dan beberapa dekade (19972006 vs 2007-2016) untuk menunjukkan perubahan dari waktu ke waktu. Bagian kedua, fokus pada analisis komunitas ilmuwan perpajakan di area akuntansi. Namun karena keterbatasan data sitasi yang ada dalam publikasi penelitian di Indonesia, maka untuk pendekatan analisis komunitas yang digunakan dalam penelitian ini hanya analisis sitasi. Analisis sitasi diambil dari Google Scholar (seperti Rosenstreich \& Wooliscroft 2009). Google Scholar dipilih dengan pertimbangan ketersediaan data sitasi dan juga salah satu pengukuran Science and Technology Index (SINTA) score (Kemenristekdikti dan Lembaga Ilmu Pengetahuan Indonesia 2017) juga menggunakan jumlah sitasi di Google Scholar.

Penelitian ini memiliki setidaknya tiga kontribusi bagi literatur akuntansi. Pertama, memberikan bukti sejarah perkembangan penelitian perpajakan dalam akuntansi di Indonesia periode 20 tahun (1997-2016), sehingga dapat menjadi bahan evaluasi kinerja akademisi akuntansi (Bonner et al. 2006) dan bahan kajian pustaka untuk penelitian selanjutnya yang akan meneliti akuntansi dalam bidang kajian perpajakan. Kedua, artikel ini memberikan bukti bahwa market share artikel perpajakan sebesar $17 \%$ dari 494 penelitian akuntansi; pangsa pasar artikel perpajakan mengalami peningkatan selama dua dekade dan pangsa pasar tertinggi ada di Jurnal Akuntansi dan Keuangan (JAK) dan EKUITAS Jurnal Ekonomi dan Keuangan; topik yang telah banyak diteliti adalah perpajakan yang terkait dengan akuntansi keuangan (43\%) dan keperilakukan (24\%); metode penelitian yang mendominasi adalah metode kuantitatif (64\%); metode pengumpulan data yang paling banyak digunakan archival (36\%), survei (28\%), dan kajian pustaka (20\%); $49 \%$ artikel perpajakan telah mendapatkan sitasi; jurnal yang paling banyak mendapatkan sitasi adalah Jurnal Akuntansi dan Keuangan (JAK). Ketiga, kajian ini memberikan pengetahuan kepada peneliti selanjutnya tentang isu/topik umum, metode, disiplin ilmu yang telah dipelajari, penulis yang telah memberi kontribusi pada pengetahuan, jurnal yang telah menerbitkan karya penting di bidang ini, market share dan journal share penelitian perpajakan sebagai subarea akuntansi, besarnya dampak penelitian perpajakan dan menyarankan beberapa hal penting untuk penelitian selanjutnya.

\section{PEMETAAN AREA}

\section{Pemilihan Artikel}

Penelitian ini mengidentifikasi artikel perpajakan pada jurnal-jurnal yang masih terakreditasi pada tahun 2017, terpublikasi secara online dan mencakup kajian bidang akuntansi. Berdasarkan kriteria tersebut, diperoleh 7 (tujuh) jurnal (tabel 1) yaitu EKUITAS Jurnal Ekonomi dan Keuangan (selanjutnya disingkat EKUITAS); Jurnal Akuntansi Keuangan Indonesia (selanjutnya disingkat JAKI); Jurnal Akuntansi Multiparadigma (selanjutnya disingkat JAMAL); Jurnal Akuntansi dan Keuangan (selanjutnya disingkat JAK); Journal of Economics, Business, \& Accountancy VENTURA (selanjutnya disingkat VENTURA); Jurnal Akuntansi dan Auditing Indonesia (selanjutnya disingkat JAAI) dan Jurnal Akuntansi. Namun, Jurnal Akuntansi yang terbit sejak tahun 2004 hanya menampilkan secara online 3 tahun publikasi terakhir yaitu tahun 2017-2015. Meski demikian, karena jurnal Akuntansi merupakan jurnal yang secara khusus memberikan ruang kajian perpajakan maka sangat dimungkinkan terdapat banyak artikel perpajakan yang dapat menjadi bahan memotret sejarah perkembangan penelitian perpajakan. Oleh karena itu, 
jurnal Akuntansi tetap dimasukkan dalam pengamatan meski hanya untuk pengamatan tahun 2016 dan 2015. Jadi 7 (tujuh) jurnal terakreditasi di atas digunakan untuk meninjau penelitian perpajakan dalam akuntansi.

Penelitian ini memilih periode amatan 1997 sampai dengan 2016 (periode 20 tahun). Pertimbangan tahun 1997 sebagai awal pengamatan adalah jurnal akreditasi yang memberikan ruang kajian bidang perpajakan ditemukan pada jurnal EKUITAS dan terbit pertama kali tahun 1997 serta terdapat 3 artikel perpajakan pada edisi pertama penerbitannya. Sedangkan tahun 2016 sebagai akhir pengamatan adalah dari 7 jurnal yang menjadi sampel penelitian, 5 (lima) jurnal memiliki edisi publikasi bulan Desember (tabel 1 kolom 4). Hal itu menyebabkan jika tahun 2017 dimasukkan dalam pengamatan maka data tidak lengkap untuk 5 jurnal sampel. Pertimbangan tersebut yang menjadikan tahun 2016 sebagai periode akhir amatan. Selain pengamatan perkembangan penelitian perpajakan selama 20 tahun, penelitian ini juga membagi menjadi beberapa dekade untuk menunjukkan perubahan

Tabel 1. Jurnal-Jurnal Terakreditasi dan Tersedia Online

\begin{tabular}{|c|c|c|c|c|c|c|c|}
\hline No & Nama Jurnal & $\begin{array}{c}\text { Tahun } \\
\text { Pengamatan }\end{array}$ & $\begin{array}{c}\text { Edisi } \\
\text { Penerbitan }\end{array}$ & $\begin{array}{l}\text { Status TerAkreditasi } \\
\text { SK Dirjen DIKTI }\end{array}$ & Alamat Website & Kajian Bidang & $\begin{array}{c}\text { Jml } \\
\text { Artikel } \\
\text { Pajak* }\end{array}$ \\
\hline 1 & $\begin{array}{l}\text { EKUITAS Jurnal } \\
\text { Ekonomi dan } \\
\text { Keuangan }\end{array}$ & 2016-1997 & $\begin{array}{l}\text { Maret, Juni, } \\
\text { September, } \\
\text { Desember }\end{array}$ & $\begin{array}{l}\text { No. } \\
\text { 80/DIKTI/Kep/2012 } \\
\text { dan e-ISSN 2548- } \\
5024\end{array}$ & $\begin{array}{l}\text { https://ejournal.stiesia. } \\
\text { ac.id/ekuitas/index }\end{array}$ & $\begin{array}{l}\text { Ekonomi dan Keuangan, } \\
\text { khususnya bidang } \\
\text { Akuntansi, Manajemen, } \\
\text { Pasar Modal, Hukum } \\
\text { Bisnis, Perpajakan, } \\
\text { Sistem Informasi, serta } \\
\text { bidang Ekonomi dan } \\
\text { Keuangan lainnya }\end{array}$ & 17 \\
\hline 2 & $\begin{array}{l}\text { Jurnal Akuntansi } \\
\text { Keuangan } \\
\text { Indonesia (JAKI) }\end{array}$ & 2016-2004 & $\begin{array}{l}\text { Juni dan } \\
\text { Desember }\end{array}$ & $\begin{array}{l}\text { No. } \\
\text { 80/DIKTI/Kep/2012 } \\
\text { untuk periode } 2012 \text { - } \\
2017\end{array}$ & $\begin{array}{l}\text { http://jaki.ui.ac.id/inde } \\
\text { x.php/home/index }\end{array}$ & Akuntansi dan Keuangan & 12 \\
\hline 3 & $\begin{array}{l}\text { Jurnal Akuntansi } \\
\text { Multiparadigma } \\
\text { (JAMAL) }\end{array}$ & 2016-2010 & $\begin{array}{l}\text { April, Agustus, } \\
\text { Desember }\end{array}$ & $\begin{array}{l}\text { No. } 212 / \mathrm{P} / 2014 \\
\text { Periode 2014-2019 }\end{array}$ & $\begin{array}{l}\text { http://jamal.ub.ac.id/in } \\
\text { dex.php/jamal/index }\end{array}$ & Akuntansi & 15 \\
\hline 4 & $\begin{array}{l}\text { Jurnal Akuntansi } \\
\text { dan Keuangan } \\
\text { (JAK) }\end{array}$ & 2016-1999 & $\begin{array}{l}\text { Mei dan } \\
\text { November }\end{array}$ & $\begin{array}{l}\text { No. 36a/E/KPT/2016, } \\
\text { tanggal } 23 \text { Mei } 2016 \\
\text { berlaku sampai } \\
\text { dengan 23 Mei } 2021 \\
\text { dan e-ISSN 2338- } \\
8137\end{array}$ & $\begin{array}{l}\text { http://jurnalakuntansi. } \\
\text { petra.ac.id/ }\end{array}$ & $\begin{array}{l}\text { Akuntansi dan Keuangan } \\
\text { umumnya, khususnya } \\
\text { bidang Akuntansi } \\
\text { Keuangan Pasar Modal, } \\
\text { Akuntansi Manajemen, } \\
\text { Sistem Informasi } \\
\text { Akuntansi, Auditing, } \\
\text { Perpajakan. }\end{array}$ & 19 \\
\hline 5 & $\begin{array}{l}\text { Journal of } \\
\text { Economics, } \\
\text { Business, \& } \\
\text { Accountancy } \\
\text { VENTURA }\end{array}$ & 2016-2010 & $\begin{array}{l}\text { April, Agustus, } \\
\text { Desember }\end{array}$ & $\begin{array}{l}\text { No. } \\
\text { 80/DIKTI/Kep./2012 }\end{array}$ & $\begin{array}{l}\text { https://journal.perban } \\
\text { as.ac.id/ }\end{array}$ & $\begin{array}{l}\text { Ekonomi, Bisnis, } \\
\text { Perbankan, Manajemen } \\
\text { dan Akuntansi }\end{array}$ & 2 \\
\hline 6 & $\begin{array}{l}\text { Jurnal Akuntansi } \\
\text { dan Auditing } \\
\text { Indonesia (JAAI) }\end{array}$ & 2016-2002 & $\begin{array}{l}\text { Juni dan } \\
\text { Desember }\end{array}$ & $\begin{array}{l}\text { No. } \\
\text { SK: 36a/E/KPT/2016 } \\
\text { E-ISSN: 2528-6528 }\end{array}$ & $\begin{array}{l}\text { https://journal.uii.ac.id } \\
\text { /index.php/JAAI }\end{array}$ & Akuntansi dan Auditing & 7 \\
\hline 7 & $\begin{array}{l}\text { Jurnal } \\
\text { Akuntansi*** }\end{array}$ & 2016-2015 & $\begin{array}{l}\text { Januari, Mei, } \\
\text { September }\end{array}$ & $\begin{array}{l}\text { No. 1/E/KPT/2015 ter } \\
\text { tanggal } 21 \text { Septem- } \\
\text { ber } 2015 \text { dan e-ISSN } \\
2549-8800\end{array}$ & $\begin{array}{l}\text { http://journal.untar.ac. } \\
\text { id/index.php/akuntansi } \\
\text { http://ecojoin.org/index } \\
\text {.php/EJA }\end{array}$ & $\begin{array}{l}\text { Akuntansi Internasional } \\
\text { dan Keuangan; } \\
\text { Akuntansi Manajemen } \\
\text { x dan Biaya; Perpajakan; } \\
\text { Auditing; Sistem } \\
\text { Informasi Akuntansi; } \\
\text { Pendidikan Akuntansi; } \\
\text { Akuntansi Lingkungan } \\
\text { dan Sosial; Akuntansi } \\
\text { untuk Organisasi Non- } \\
\text { Profit; Akuntansi Sektor } \\
\text { Publik; Tata Kelola: } \\
\text { Akuntansi/Keuangan; } \\
\text { Masalah Etika dalam } \\
\text { Pelaporan Akuntansi dan } \\
\text { Keuangan; Corporate } \\
\text { Finance; Investasi, } \\
\text { Derivatif; Perbankan; } \\
\text { Pasar Modal di Ekonomi } \\
\text { Berkembang }\end{array}$ & $11^{* * *}$ \\
\hline
\end{tabular}


kan tiap tahunnya dan paper pajak selama 5 tahun terakhir dari tahun 2008-2012 cenderung mengalami stagnasi.

\section{Klasifikasi Artikel}

\section{Topik}

Dipandu oleh penelitian sebelumnya (Shields 1997, dan Hesford et al. 2007), penelitian ini mengklasifikasikan setiap artikel berdasarkan topik, metode, dan disiplin sumber. Penelitian ini mengklasifikasikan topik penelitian ke dalam 4 kelompok yaitu topik akuntansi keuangan, evaluasi kebijakan, keperilakuan dan lain-lain. Tabel 3A menunjukkan sekitar 37\% dari artikel perpajakan berkaitan dengan topik akuntansi keuangan, $20 \%$ pada topik keperilakuan, $12 \%$ pada topik evaluasi kebijakan dan $17 \%$ pada topik lain-lain. Tiga topik yang mengalami penurunan selama dua dekade adalah akuntansi keuangan (dari 55\% menjadi 38\%), topik evaluasi kebijakan (dari 18\% menjadi $12 \%$ ) dan topik lain-lain (dari $27 \%$ menjadi 16\%). Sedangkan topik keperilakuan mengalami kenaikan pada dua dekade yang ada yaitu dari sama sekali tidak ada meningkat menjadi 34\%. Hasil ini bisa dikatakan sama (meskipun secara langsung tidak sebanding) dengan hasil yang diperoleh Al Irsyad \& Martani (2013) dengan menggunakan sampel artikel perpajakan di jurnal internasional akuntansi terbaik dan menemukan bahwa sebagian penulis pajak lebih tertarik di dalam meneliti respon dan perilaku manajer perusahaan di dalam menanggapi aturan pajak yan berlaku (riset perencanaan pajak) daripada meneliti efektivitas pemberlakuan aturan pajak tersebut (riset kebijakan pajak) dan faktor-faktor yang mempengaruhi kepatuhan pajak (riset kepatuhan). Demikian juga dengan hasil yang ditemukan pada jurnal internasional khusus kajian perpajakan (yaitu Journal of the American Taxation Association), Hutchison and White (2003) melaporkan indikasi bahwa dari tahun 1979-2000, jumlah artikel terbesar berkaitan dengan kepatuhan pajak, diikuti dengan perencanaan pajak, dan kebijakan pajak.

Topik penelitian yang masuk dalam kategori akuntansi keuangan adalah biaya tanggung jawab sosial, manajemen laba, daya prediksi pajak, konservatisma akuntansi, akuntansi perpajakan, perencanaan pajak, book tax difference, penghindaran pajak, aktivitas tax shelter, pajak tangguhan, transfer pricing, transaksi instrumen keuangan derivatif SWAP, agresifitas pelaporan keuangan dan pajak, persistensi laba, foreign direct investment, dan pelaporan pajak terkait peringkat obligasi. Topik akuntansi keuangan yang paling banyak diteliti selama 20 tahun adalah book tax difference (7\%) dan akuntansi perpajakan (7\%). Topik penelitian yang masuk dalam kategori evaluasi kebijakan adalah kebijakan amnesti pajak, peraturan daerah retribusi/iuran pasar, pemahaman Wajib Pajak terhadap UndangUndang, sistem pajak nasional, regulasi dan perundang-undangan anti penghindaran pajak, sistem monitoring pelaporan pembayaran pajak (MP3), pemotongan dan pemungutan pajak di pemerintahan, Peraturan Pemerintah Republik Indonesia No. 51 Tahun 2008 tentang pajak jasa bisnis konstruksi, kebijakan dividen dan perubahan peraturan perpajakan. Topik evaluasi kebijakan yang paling banyak diteliti selama 20 tahun adalah kebijakan dividen dan perubahan peraturan perpajakan $(2 \%)$.

Topik penelitian yang masuk dalam kategori keperilakuan adalah kepatuhan Wajib Pajak Orang Pribadi, ketidakpatuhan Wajib Pajak Orang Pribadi, kepatuhan Wajib Pajak, kepatuhan Wajib Pajak Badan, kepatuhan Wajib Pajak industri bank, perilaku ke(tidak)patuhan Wajib Pajak UMKM, kepatuhan Wajib Pajak Lembaga Perkreditan Desa, kepatuhan Pengusaha Kena Pajak dan modernisasi sistem, kesadaran dan kepatuhan Wajib Pajak-Account Representative, kepatuhan perpajakan sukarela, dan motivasi dalam tax planning. Topik keperilakuan yang paling banyak diteliti selama 20 tahun adalah kepatuhan Wajib Pajak Orang Pribadi (11\%).

Topik penelitian yang masuk dalam kategori lain-lain adalah pemaknaan pajak, akuntabilitas perpajakan, sistem informasi pajak, corporate social responsibility dan penghindaran pajak, pendidikan perpajakan, SPT Tahunan 21, PPh Pasal 21, pengetahuan Wajib Pajak, e-commerce, pajak penghasilan $(\mathrm{PPh})$, penggabungan usahapajak penghasilan dan tax literacy rate. Topik lainlain yang paling banyak diteliti selama 20 tahun adalah pemaknaan pajak (2\%) dan pajak penghasilan (2\%).

\section{Metode Penelitian}

Penelitian ini mengklasifikasikan metode penelitian menjadi 2 kategori yaitu kategori pertama ditunjukkan dalam Tabel 3B Panel B1 (mencakup metode kuantitatif, kualitatif dan campuran) dan kategori kedua ditunjukkan dalam Tabel 3B Panel B2 (mencakup metode eksperimen, survei, arsip, kajian pustaka, studi kasus, deskriptif, interpretif, dan fenomenologi). Tabel 3B, Panel B1 menunjukkan bahwa $64 \%$ penelitian perpajakan menggunakan metode kuantitatif, 35\% meng- 
Tabel 3A. Klasifikasi Artikel_-Topik Penelitian Perpajakan

\begin{tabular}{|c|c|c|c|}
\hline Topik Penelitian ${ }^{\mathrm{a}}$ & $\begin{array}{c}\text { 1997-2016 } \\
\left.\text { Artikel (Pct }{ }^{\mathrm{a}}\right)\end{array}$ & $\begin{array}{c}1997-2006 \\
\text { Artikel (Pcta) }\end{array}$ & $\begin{array}{c}2007-2016 \\
\text { Artikel (Pcta) }\end{array}$ \\
\hline Akuntansi Keuangan & $31^{*}(37 \%)$ & $12^{* *}(55 \%)$ & $19^{* * * *}(38 \%)$ \\
\hline Biaya Tanggung Jawab Sosial & $1(1 \%)$ & $0(0 \%)$ & $1(2 \%)$ \\
\hline Manajemen Laba & $3(4 \%)$ & $1(5 \%)$ & $2(4 \%)$ \\
\hline Daya Prediksi Pajak & $1(1 \%)$ & $0(0 \%)$ & $1(2 \%)$ \\
\hline Konservatisma Akuntansi & $1(1 \%)$ & $0(0 \%)$ & $1(2 \%)$ \\
\hline Akuntansi Perpajakan & $5(7 \%)$ & $5(23 \%)$ & $0(0 \%)$ \\
\hline Perencanaan Pajak & $2(6 \%)$ & $2(9 \%)$ & $0(0 \%)$ \\
\hline Book Tax Difference & $6(7 \%)$ & $0(0 \%)$ & $6(12 \%)$ \\
\hline Penghindaran Pajak & $4(5 \%)$ & $0(0 \%)$ & $4(8 \%)$ \\
\hline Aktivitas Tax Shelter & $1(1 \%)$ & $0(0 \%)$ & $1(2 \%)$ \\
\hline Pajak Tangguhan & $3(4 \%)$ & $1(5 \%)$ & $2(4 \%)$ \\
\hline Transfer Pricing & $2(2 \%)$ & $1(5 \%)$ & $1(2 \%)$ \\
\hline Transaksi Instrumen Keuangan Derivatif SWAP & $1(1 \%)$ & $1(5 \%)$ & $0(0 \%)$ \\
\hline Agresifitas Pelaporan Keuangan dan Pajak & $1(\%)$ & $(0 \%)$ & $1(\%)$ \\
\hline Persistensi Laba & $1(\%)$ & $(0 \%)$ & $1(\%)$ \\
\hline Foreign Direct Investment & $1(\%)$ & $(0 \%)$ & $1(\%)$ \\
\hline Pelaporan Pajak \& Peringkat Obligasi & $1(\%)$ & $(0 \%)$ & $1(\%)$ \\
\hline Evaluasi Kebijakan & $10 *(12 \%)$ & $4^{* *}(18 \%)$ & $6^{* * *}(12 \%)$ \\
\hline Kebijakan Amnesti Pajak & $1(1 \%)$ & $(0 \%)$ & $1(2 \%)$ \\
\hline Peraturan Daerah Retribusi/Iuran Pasar & $1(1 \%)$ & $1(5 \%)$ & $0(0 \%)$ \\
\hline Pemahaman Wajib Pajak terhadap Undang-Undang & $1(1 \%)$ & $1(5 \%)$ & $0(0 \%)$ \\
\hline Sistem Pajak Nasional & $1(1 \%)$ & $1(5 \%)$ & $0(0 \%)$ \\
\hline Regulasi dan Perundang-Undagan Anti Penghindaran Pajak & $1(1 \%)$ & $0(0 \%)$ & $1(2 \%)$ \\
\hline Sistem Monitoring Pelaporan Pembayaran Pajak (MP3) & $1(1 \%)$ & $1(5 \%)$ & $0(0 \%)$ \\
\hline Pemotongan dan Pemungutan Pajak di Pemerintahan & $1(1 \%)$ & $(0 \%)$ & $1(2 \%)$ \\
\hline PP RI Nomor 51 Tahun 2008 Pajak Jasa Bisnis Konstruksi & $1(1 \%)$ & $0(0 \%)$ & $1(2 \%)$ \\
\hline Kebijakan Dividen dan Perubahan Peraturan Perpajakan & $2(2 \%)$ & $0(0 \%)$ & $2(4 \%)$ \\
\hline Keperilakuan & $17 *(20 \%)$ & $0 * *(0 \%)$ & $17 * * *(34 \%)$ \\
\hline Kepatuhan Wajib Pajak Orang Pribadi & $9(11 \%)$ & $0(0 \%)$ & $7(14 \%)$ \\
\hline Ketidakpatuhan Wajib Pajak Orang Pribadi & $1(1 \%)$ & $0(0 \%)$ & $1(2 \%)$ \\
\hline Kepatuhan Wajib Pajak & $1(1 \%)$ & $0(0 \%)$ & $1(2 \%)$ \\
\hline Kepatuhan Wajib Pajak Badan & $3(4 \%)$ & $0(0 \%)$ & $2(4 \%)$ \\
\hline Kepatuhan Wajib Pajak Industri Bank & $1(1 \%)$ & $0(0 \%)$ & $1(2 \%)$ \\
\hline Perilaku Ke(tidak)patuhan Wajib Pajak UMKM & $1(1 \%)$ & $0(0 \%)$ & $1(2 \%)$ \\
\hline Kepatuhan Wajib Pajak Lembaga Perkreditan Desa & $1(1 \%)$ & $0(0 \%)$ & $1(2 \%)$ \\
\hline Kepatuhan PKP dan Modernisasi Sistem & $1(1 \%)$ & $0(0 \%)$ & $1(2 \%)$ \\
\hline Kesadaran dan Kepatuhan Wajib Pajak-Account Representative & $1(1 \%)$ & $0(0 \%)$ & $1(2 \%)$ \\
\hline Kepatuhan Perpajakan Sukarela & $1(1 \%)$ & $0(0 \%)$ & $1(2 \%)$ \\
\hline Motivasi dalam Tax Planning & $1(\%)$ & $0(0 \%)$ & $1(\%)$ \\
\hline Lain-Lain & $14^{*}(17 \%)$ & $6^{* *}(27 \%)$ & $8^{* * * *}(16 \%)$ \\
\hline Pemaknaan Pajak & $2(2 \%)$ & $0(0 \%)$ & $2(4 \%)$ \\
\hline Akuntabilitas Perpajakan & $1(1 \%)$ & $0(0 \%)$ & $1(2 \%)$ \\
\hline Sistem Informasi Pajak & $1(1 \%)$ & $0(0 \%)$ & $1(2 \%)$ \\
\hline Corporate Social Responsibility dan Penghindaran Pajak & $1(1 \%)$ & $0(0 \%)$ & $1(2 \%)$ \\
\hline Pendidikan Perpajakan & $1(1 \%)$ & $0(0 \%)$ & $1(2 \%)$ \\
\hline SPT Tahunan 21 & $1(1 \%)$ & $0(0 \%)$ & $1(2 \%)$ \\
\hline PPh Pasal 21 & $1(1 \%)$ & $0(0 \%)$ & $1(2 \%)$ \\
\hline Pengetahuan Wajib Pajak & $1(1 \%)$ & $1(5 \%)$ & $0(0 \%)$ \\
\hline E Commerce & $1(1 \%)$ & $1(5 \%)$ & $0(0 \%)$ \\
\hline Pajak Penghasilan & $2(2 \%)$ & $2(9 \%)$ & $0(0 \%)$ \\
\hline Penggabungan Usaha dan Pajak Penghasilan & $1(1 \%)$ & $1(5 \%)$ & $0(0 \%)$ \\
\hline Tax Literacy Rate & $1(1 \%)$ & $1(5 \%)$ & $0(0 \%)$ \\
\hline Total*, ** dan **** & $83(100 \%)$ & $22(100 \%)$ & $50(100 \%)$ \\
\hline
\end{tabular}

gunakan metode kualitatif dan 1\% menggunakan metode campuran. Jurnal yang paling banyak menggunakan metode kuantitatif adalah JAKI (13\%), jurnal Akuntansi (13\%), JAK (11\%) dan JAMAL (10\%). Sedangkan jurnal yang paling banyak menggunakan metode kualitatif adalah EKUITAS (13\%), JAK (12\%), dan JAMAL (8\%). Sedangkan jurnal yang ada artikel perpajakan yang menggunakan metode campuran adalah JAAI (1\%). Hasil ini seperti temuan Al Irsyad \& Martani (2013) namun menggunakan sampel berbeda dan menemukan metodologi yang paling sering digunakan di dalam riset perpajakan pada beberapa jurnal internasional terbaik di bidang
Akuntansi periode 2008-2012 adalah archival/ empirical yang merupakan salah satu karakteristik dari riset positif.

Tabel 3B, Panel B2 menunjukkan selama periode 20 tahun, archival (36\%), survei (28\%) dan kajian pustaka (20\%) merupakan tiga metode penelitian yang paling dominan. Berdasarkan pengamatan dua dekade, terjadi peningkatan metode kualitatif seperti studi kasus, interpretif, fenomenologi, dan deskriptif. Metode archival, survei, eksperimen juga mengalami kenaikan. Sedangkan metode yang mengalami penurunan adalah metode kajian pustaka. Metode kajian pustaka paling dominan dilakukan pada dekade 
pertama. Berdasarkan pengamatan pada artikel perpajakan pada beberapa jurnal internasional terbaik di bidang Akuntansi, Coyne et al. (2010), Oler et al. (2010), Al Irsyad dan Martani (2013), dan Rusli (2015) juga menemukan sebagian besar peneliti pajak menggunakan metodologi achivallempirical. Demikian juga dengan hasil yang ditemukan pada jurnal internasional khusus kajian perpajakan (yaitu Journal of the American Taxation Association), Hutchison and White (2003) melaporkan indikasi bahwa dari tahun 1979 -2000, untuk metodologi, studi data archival mendominasi, diikuti oleh riset analitis, dan kemudian kaitan antara studi perilaku dan kuesioner.

Tabel 3B. Klasifikasi Artikel-Metode Penelitian

Panel B1: Metode Penelitian Perpajakan—Jurnal

\begin{tabular}{|c|c|c|c|c|c|c|c|c|c|}
\hline \multirow[b]{2}{*}{ Jurnal } & \multicolumn{2}{|c|}{ Metode Kuantitatif } & \multirow{2}{*}{$\begin{array}{c}\text { Total } \\
1997-2016 \\
\text { Artikel } \\
(\text { Pcta) }\end{array}$} & \multicolumn{2}{|c|}{ Metode Kualitatif } & \multirow{2}{*}{$\begin{array}{c}\text { Total } \\
1997-2016 \\
\text { Artikel } \\
\text { (Pct })\end{array}$} & \multicolumn{2}{|c|}{ Metode Campuran } & \multirow{2}{*}{$\begin{array}{c}\text { Total } \\
1997-2016 \\
\text { Artikel } \\
(\text { Pcta })\end{array}$} \\
\hline & $\begin{array}{c}\text { 1997-2006 } \\
\text { Artikel (Pcta) }\end{array}$ & $\begin{array}{c}2007-2016 \\
\text { Artikel (Pcta) }\end{array}$ & & $\begin{array}{c}\text { 1997-2006 } \\
\text { Artikel (Pcta) }\end{array}$ & $\begin{array}{c}\text { 2007-2016 } \\
\text { Artikel (Pcta) }\end{array}$ & & $\begin{array}{c}\text { 1997-2006 } \\
\text { Artikel (Pcta) }\end{array}$ & $\begin{array}{c}\text { 2007-2016 } \\
\text { Artikel (Pcta) }\end{array}$ & \\
\hline EKUITAS & \%) & $5(6 \%)$ & $6(7 \%)$ & $8(10 \%)$ & $3(4 \%)$ & $11(13 \%)$ & $0(0 \%)$ & $0(0 \%)$ & $0(0 \%)$ \\
\hline JAKI & $2(2 \%)$ & $9(11 \%)$ & $11(13 \%)$ & $0(0 \%)$ & $1(1 \%)$ & $1(1 \%)$ & $0(0 \%)$ & $0(0 \%)$ & $0(0 \%)$ \\
\hline JAMAL & $0(0 \%)$ & $8(10 \%)$ & $8(10 \%)$ & $0(0 \%)$ & $7(8 \%)$ & $7(8 \%)$ & $0(0 \%)$ & $0(0 \%)$ & $0(0 \%)$ \\
\hline JAK & $3(4 \%)$ & $6(7 \%)$ & $9(11 \%)$ & $7(8 \%)$ & $3(4 \%)$ & $10(12 \%)$ & $0(0 \%)$ & $0(0 \%)$ & $0(0 \%)$ \\
\hline VENTURA & $0(0 \%)$ & $2(2 \%)$ & $2(2 \%)$ & $0(0 \%)$ & $0(0 \%)$ & $0(0 \%)$ & $0(0 \%)$ & $0(0 \%)$ & $0(0 \%)$ \\
\hline JAAI & $1(1 \%)$ & $5(6 \%)$ & $6(7 \%)$ & $0(0 \%)$ & $0(0 \%)$ & $0(0 \%)$ & $0(0 \%)$ & $1(1 \%)$ & $1(1 \%)$ \\
\hline AKUNTANSI* & $0(0 \%)$ & $11(13 \%)$ & $11(13 \%)$ & $0(0 \%)$ & $0(0 \%)$ & $0(0 \%)$ & $0(0 \%)$ & $0(0 \%)$ & $0(0 \%)$ \\
\hline Total & $7(8 \%)$ & $46(55 \%)$ & $53(64 \%)$ & $15(18 \%)$ & $14(17 \%)$ & $29(35 \%)$ & $0(0 \%)$ & $1(1 \%)$ & $1(1 \%)$ \\
\hline
\end{tabular}

a persentasi dari total jumlah artikel perpajakan (83 artikel)

*pengamatan hanya tahun 2016 dan 2015

Panel B2: Metode Penelitian Perpajakan

\begin{tabular}{lccc}
\multicolumn{1}{c}{$\begin{array}{c}\text { Metode } \\
\text { Penelitian }\end{array}$} & $\begin{array}{c}1997-2016 \\
\text { Artikel (Pcta) }\end{array}$ & $\begin{array}{c}1997-2006 \\
\text { Artikel (Pcta) }\end{array}$ & $\begin{array}{c}2007-2016 \\
\text { Artikel (Pcta) }\end{array}$ \\
\hline Eksperimen & $1(1 \%)$ & $0(0 \%)$ & $1(2 \%)$ \\
Survei & $23(28 \%)$ & $5(23 \%)$ & $18(30 \%)$ \\
Archival & $30(36 \%)$ & $2(9 \%)$ & $28(46 \%)$ \\
Kajian Pustaka & $17(20 \%)$ & $14(64 \%)$ & $3(5 \%)$ \\
Studi Kasus & $5(6 \%)$ & $0(0 \%)$ & $5(8 \%)$ \\
Deskriptif & $4(5 \%)$ & $1(5 \%)$ & $3(5 \%)$ \\
Interpretif & $2(2 \%)$ & $0(0 \%)$ & $2(3 \%)$ \\
Fenomenologi & $1(1 \%)$ & $0(0 \%)$ & $1(2 \%)$ \\
Total & $83(100 \%)$ & $22(100 \%)$ & $61(100 \%)$ \\
\hline
\end{tabular}

a jumlah artikel perpajakan dengan topik riset sebagai persentase dari total jumlah artikel perpajakan di setiap periode (kolom persentase)

Tabel 4. Karakteristik Jurnal

Panel A Topik Penelitian berdasarkan Jurnal

\begin{tabular}{|c|c|c|c|c|c|}
\hline Jurnal & Akuntansi Keuangan & Evaluasi Kebijakan & Keperilakuan & Lain-Lain & Total \\
\hline EKUITAS & $10(59 \%)^{\mathrm{a}}$ & $4(24 \%)^{\mathrm{a}}$ & $2(12 \%)^{a}$ & $1(6 \%)^{\mathrm{a}}$ & $17(100 \%)^{\mathrm{a}}$ \\
\hline JAKI & $9(75 \%)$ & $2(17 \%)$ & $1(8 \%)$ & $0(0 \%)$ & $12(100 \%)$ \\
\hline JAMAL & $3(20 \%)$ & $2(13 \%)$ & $6(40 \%)$ & $4(27 \%)$ & $15(100 \%)$ \\
\hline JAK & $6(32 \%)$ & $2(11 \%)$ & $3(16 \%)$ & $8(42 \%)$ & $19(100 \%)$ \\
\hline VENTURA & $0(0 \%)$ & $0(0 \%)$ & $2(100 \%)$ & $0(0 \%)$ & $2(100 \%)$ \\
\hline JAAI & $3(43 \%)$ & $0(0 \%)$ & $3(43 \%)$ & $1(14 \%)$ & $7(100 \%)$ \\
\hline AKUNTANSI* & $7(64 \%)$ & $0(0 \%)$ & $4(36 \%)$ & $0(0 \%)$ & $11(100 \%)$ \\
\hline Total & $38(46 \%)$ & $10(12 \%)$ & $21(25 \%)$ & $14(17 \%)$ & $83(100 \%)$ \\
\hline
\end{tabular}

${ }^{a}$ persentase baris, jadi mengindiasikan cakupan topik oleh jurnal

* pengamatan hanya tahun 2016 dan 2015

$\underline{\text { Panel B1 Metode Penelitian berdasarkan Jurnal }}$

\begin{tabular}{|c|c|c|c|c|}
\hline Jurnal & Kuantitatif & Kualitatif & Campuran & Total \\
\hline EKUITAS & $6(35 \%)$ & $11(65 \%)^{a}$ & $0(0 \%)$ & $17(100 \%)$ \\
\hline JAKI & $11(92 \%)$ & $1(8 \%)$ & $0(0 \%)$ & $12(100 \%)$ \\
\hline JAMAL & $8(53 \%)$ & $7(47 \%)$ & $0(0 \%)$ & $15(100 \%)$ \\
\hline JAK & $9(47 \%)$ & $10(53 \%)$ & $0(0 \%)$ & $19(100 \%)$ \\
\hline VENTURA & $2(100 \%)$ & $0(0 \%)$ & $0(0 \%)$ & $2(100 \%)$ \\
\hline JAAI & $6(86 \%)$ & $0(0 \%)$ & $1(14 \%)$ & $7(100 \%)$ \\
\hline AKUNTANSI* & $11(100 \%)$ & $0(0 \%)$ & $0(0 \%)$ & $11(100 \%)$ \\
\hline Total & $53(64 \%)$ & $29(35 \%)$ & $1(1 \%)$ & $83(100 \%)$ \\
\hline
\end{tabular}

a persentase baris, jadi mengindiasikan cakupan topik oleh jurnal

*pengamatan hanya tahun 2016 dan 2015 
Adhikari et al. (2002) dan Dykxhoorn and Sinning (2010) mencatat bahwa ada kecenderungan penggunaan lebih besar metodologi empiris dalam penelitian akuntansi internasional.

\section{Disiplin Sumber}

Penelitian ini membedakan 5 disiplin sumber yaitu ekonomi, psikologi, sosiologi, spiritualitas, dan sistem informasi. Klasifikasi artikel berdasarkan disiplin sumber pada Tabel 3C menunjukkan selama 20 tahun disiplin ilmu ekonomi $(89 \%)$ merupakan disiplin sumber yang paling dominan dalam artikel perpajakan, diikuti oleh disiplin sumber psikologi $(5 \%)$ dan sosiologi $(4 \%)$. Analisis per dekade menunjukkan pada dekade pertama disiplin ilmu didominasi oleh ekonomi (100\%) sedangkan pada dekade kedua, meskipun masih didominasi oleh disiplin sumber ekonomi namun pada dekade kedua mulai beragam seperti psikologi, sosiologi, spiritualitas dan sistem informasi. Trend tersebut sesuai dengan yang dinyatakan oleh Shackelford and Shevlin (2001) bahwa penelitian pajak memiliki sejarah panjang di banyak disiplin ilmu dan juga sesuai dengan yang dinyatakan Hanlon (2010) bahwa penelitian pajak di akuntansi membutuhkan lebih banyak teori.

\section{Karakteristik Jurnal}

Tabel 4, Panel A, mentabulasi topik penelitian berdasarkan jurnal. Hasil menunjukkan artikel perpajakan dalam jurnal JAKI (75\%),
EKUITAS (59\%), jurnal Akuntansi (64\%) dan JAAI (43\%) didominasi dengan topik akuntansi keuangan. Topik keperilakuan sangat mendominasi di JAMAL, JAAI, VENTURA dan jurnal Akuntansi. Topik lain-lain mendominasi publikasi artikel perpajakan di JAK (42\%).

Tabel 4 Panel B1, menunjukkan metode kuantitatif mendominasi dalam jurnal VENTURA (100\%), Akuntansi (100\%), JAKI (92\%) dan JAAI (86\%). Sedangkan metode kualitatif mendominasi jurnal EKUITAS (65\%), JAK (53\%) dan JAMAL (47\%) dan metode campuran mendominasi jurnal JAAI (14\%). Tabel 4, Panel B2, menunjukkan metode kajian pustaka mendominasi jurnal EKUITAS (47\%), dan JAK (47\%). Metode eksperimen mendominasi jurnal JAKI (8\%). Metode survei mendominasi jurnal VENTURA (100\%) dan JAAI (57\%). Metode archival mendominasi jurnal JAKI (75\%), jurnal Akuntansi (64\%) dan JAAI (43\%). Metode studi kasus mendominasi jurnal JAMAL (20\%). Jurnal JAMAL juga mendominasi dalam metode interpretif (13\%) dan fenomenologi (7\%). Metode deskriptif mendominasi jurnal EKUITAS (12\%).

Tabel 4 Panel C, menunjukkan semua jurnal didominasi oleh disiplin sumber ekonomi. Artikel yang menggunakan disiplin sumber psikologi nampak di Jurnal VENTURA dan JAAI. Artikel yang menggunakan disiplin ilmu sosiologi nampak di Jurnal JAMAL dan JAAI. Sedangkan disiplin sumber spiritual mendominasi jurnal EKUITAS dan disiplin sumber sistem informasi mendominasi jurnal JAMAL.

Tabel 4. Karakteristik Jurnal

Panel B2 Metode Penelitian berdasarkan Jurnal

\begin{tabular}{lrrrrrrrrr}
\multicolumn{1}{c}{ Jurnal } & Eksperimen & Survei & Archival & $\begin{array}{c}\text { Kajian } \\
\text { Pustaka }\end{array}$ & $\begin{array}{c}\text { Studi } \\
\text { Kasus }\end{array}$ & Deskriptif & Interpretif & Fenomenologi & Total \\
\hline EKUITAS & $0(0)^{\mathrm{a}}$ & $2(12)$ & $4(23)$ & $8(47)$ & $1(6)$ & $2(12)$ & $0(0)$ & $0(0)$ & $17(100)$ \\
JAKI & $1(8)$ & $1(8)$ & $9(75)$ & $0(0)$ & $0(0)$ & $1(8)$ & $0(0)$ & $0(0)$ & $12(100)$ \\
JAMAL & $0(0)$ & $5(33)$ & $3(20)$ & $0(0)$ & $3(20)$ & $1(7)$ & $2(13)$ & $1(7)$ & $15(100)$ \\
JAK & $0(0)$ & $5(26)$ & $4(21)$ & $9(47)$ & $1(5)$ & $0(0)$ & $0(0)$ & $0(0)$ & $19(100)$ \\
VENTURA & $0(0)$ & $2(100)$ & $0(0)$ & $0(0)$ & $0(0)$ & $0(0)$ & $0(0)$ & $0(0)$ & $2(100)$ \\
JAAI & $0(0)$ & $4(57)$ & $3(43)$ & $0(0)$ & $0(0)$ & $0(0)$ & $0(0)$ & $0(0)$ & $7(100)$ \\
AKUNTANSI & $0(0)$ & $4(36)$ & $7(64)$ & $0(0)$ & $0(0)$ & $0(0)$ & $0(0)$ & $0(0)$ & $11(100)$ \\
\hline Total & $1(1)$ & $23(28)$ & $30(36)$ & $17(20)$ & $5(6)$ & $4(5)$ & $2(2)$ & $1(1)$ & $83(100)$ \\
\hline
\end{tabular}

a persentase baris (\%)

Panel C Sumber Disiplin berdasarkan Jurnal

\begin{tabular}{|c|c|c|c|c|c|c|}
\hline Jurnal & Ekonomi & $\begin{array}{l}\text { Ekonomi/ } \\
\text { Psikologi }\end{array}$ & $\begin{array}{l}\text { Ekonomi/ } \\
\text { Sosiologi }\end{array}$ & $\begin{array}{c}\text { Ekonomi/ } \\
\text { Spiritualitas }\end{array}$ & $\begin{array}{c}\text { Akuntansi/ } \\
\text { Sistem Informasi }\end{array}$ & Total \\
\hline EKUITAS & $15(88 \%)$ & $1(6 \%)$ & $0(0 \%)$ & $1(6 \%)$ & $0(0 \%)$ & $17(100 \%)$ \\
\hline JAKI & $12(100 \%)$ & $0(0 \%)$ & $0(0 \%)$ & $0(0 \%)$ & $0(0 \%)$ & $12(100 \%)$ \\
\hline JAMAL & $12(80 \%)$ & $0(0 \%)$ & $2(13 \%)$ & $0(0 \%)$ & $1(7 \%)$ & $15(100 \%)$ \\
\hline JAK & $18(95 \%)$ & $1(5 \%)$ & $0(0 \%)$ & $0(0 \%)$ & $0(0 \%)$ & $19(100 \%)$ \\
\hline VENTURA & $1(50 \%)$ & $1(50 \%)$ & $0(0 \%)$ & $0(0 \%)$ & $0(0 \%)$ & $2(100 \%)$ \\
\hline JAAI & $5(71 \%)$ & $1(14 \%)$ & $1(14 \%)$ & $0(0 \%)$ & $0(0 \%)$ & $7(100 \%)$ \\
\hline AKUNTANSI & $11(100 \%)$ & $0(0 \%)$ & $0(0 \%)$ & $0(0 \%)$ & $0(0 \%)$ & $11(100 \%)$ \\
\hline Total & $74(89 \%)$ & $4(5 \%)$ & $3(4 \%)$ & $1(1 \%)$ & $1(1 \%)$ & $83(100 \%)$ \\
\hline
\end{tabular}




\section{Karakteristik Artikel}

Tabel 5 mentabulasi metode penelitian dengan topik penelitian. Tabel 5, Panel A1 menunjukkan metode penelitian kuantitatif mendominasi topik akuntansi keuangan (51\%) dan keperilakuan (30\%). Metode kualitatif mendominasi topik lainlain (34\%), akuntansi keuangan (31\%), dan evaluasi kebijakan (21\%). Sedangkan topik keperilakuan ada juga yang menggunakan metode campuran (mix).

Tabel 5, Panel A2 menunjukkan topik keperilakuan didominasi menggunakan metode survei. Sedangkan topik akuntansi keuangan didominasi dengan metode archival. Topik evaluasi kebijakan didominasi dengan metode deskriptif. Topik lain-lain didominasi dengan metode kajian pustaka dan survei. Hasil yang sedikit berbeda ditemukan pada artikel perpajakan di jurnal internasional khusus kajian perpajakan (yaitu Journal of the American Taxation Association) dan Hutchison and White (2003) menemukan topik yang mengeksplorasi kebijakan pajak didominasi oleh analisis data archival. Hutchison and White (2003) berpendapat bahwa hal ini tampaknya logis mengingat banyak artikel tersebut menguji masalah seperti distribusi pajak di seluruh kelompok Wajib Pajak. Baik studi analitikal dan kuesioner agak jauh dari metode penelitian ini. Sebaliknya, area perencanaan pajak didominasi oleh dua metodologi yaitu riset analitik dan studi archival.

Table 5. Karakteristik Artikel: Tabulasi Silang Metode dan Topik

Tabel 5. Panel A1 Topik Penelitian Perpajakan berdasarkan Metode

\begin{tabular}{|c|c|c|c|c|c|}
\hline \multirow{2}{*}{$\begin{array}{l}\text { Metode } \\
\text { Penelitian }\end{array}$} & \multicolumn{4}{|c|}{ Topik Penelitian } & \multirow[b]{2}{*}{ Total } \\
\hline & $\begin{array}{l}\text { Keperi- } \\
\text { lakuan }\end{array}$ & $\begin{array}{l}\text { Akuntansi } \\
\text { Keuangan }\end{array}$ & $\begin{array}{c}\text { Evaluasi } \\
\text { Kebijakan }\end{array}$ & $\begin{array}{l}\text { Lain- } \\
\text { Lain }\end{array}$ & \\
\hline Kualitatif & $4(14 \%)$ & $9(31 \%)$ & $6(21 \%)$ & $10(34 \%)$ & $29(100 \%)$ \\
\hline Kuantitatif & $16(30 \%)$ & $27(51 \%)$ & $4(8 \%)$ & $6(11 \%)$ & $53(100 \%)$ \\
\hline Campuran & $1(100 \%)$ & $0(0 \%)$ & $0(0 \%)$ & $0(0 \%)$ & $1(100 \%)$ \\
\hline Total & $21(25 \%)$ & $36(43 \%)$ & $10(12 \%)$ & $16(19 \%)$ & $83(100 \%)$ \\
\hline
\end{tabular}

Tabel 5. Panel A2: Metode Penelitian Perpajakan berdasarkan Topik

\begin{tabular}{lccccc}
\hline \multirow{2}{*}{$\begin{array}{c}\text { Metode } \\
\text { Penelitian }\end{array}$} & \multicolumn{4}{c}{ Topik Penelitian } & \\
\cline { 2 - 5 } & $\begin{array}{c}\text { Keperi- Akuntansi } \\
\text { lakuan }\end{array}$ & $\begin{array}{c}\text { Evaluasi } \\
\text { Keuangan }\end{array}$ & $\begin{array}{c}\text { Lain- } \\
\text { Tebijakan }\end{array}$ & Lain & \\
\hline Eksperimen & 1 & 0 & 0 & 0 & 1 \\
Survei & 16 & 0 & 2 & 5 & 23 \\
Archival & 0 & 27 & 2 & 1 & 30 \\
Kajian Pustaka & 1 & 9 & 1 & 6 & 17 \\
Studi Kasus & 2 & 0 & 2 & 1 & 5 \\
Deskriptif & 1 & 0 & 3 & 0 & 4 \\
Interpretif & 0 & 0 & 0 & 2 & 2 \\
Fenomenologi & 0 & 0 & 0 & 1 & 1 \\
\hline Total & 21 & 36 & 10 & 16 & 83 \\
\hline
\end{tabular}

Tabel 6 mentabulasi silang antara metode peneltian dengan disiplin sumber. Tabel 6, Panel A menunjukkan metode kuantitatif mendominasi sumber disiplin ekonomi dan psikologi. Sedangkan metode kualitatif mendominasi sumber disiplin ekonomi dan sosiologi. Tabel 6, Panel B menunjukkan metode archival, kajian pustaka dan survei mendominasi sumber disiplin ekonomi. Sedangkan metode survei juga mendominasi sumber disiplin psikologi. Sumber disiplin spiritual dan sistem informasi digunakan dalam metode riset kajian pustaka dan survei.

Tabel 6. Karakteristik Artikel: Tabulasi Silang Metode dan Disiplin Sumber

Panel A: Metode Penelitian Perpajakan dengan Sumber Disiplin

\begin{tabular}{|c|c|c|c|c|c|c|}
\hline $\begin{array}{c}\text { Metode Riset } \\
\text { Sumber Disiplin }\end{array}$ & $\begin{array}{l}\text { Eko- } \\
\text { nomi }\end{array}$ & $\begin{array}{r}\text { Psik } \\
\text { logi }\end{array}$ & $\begin{array}{r}\text { Sosi } \\
\text { logi }\end{array}$ & $\begin{array}{r}\text { Spiritu } \\
\text { litas }\end{array}$ & $\begin{array}{l}\text { Sistem } \\
\text { Informasi }\end{array}$ & Total \\
\hline ualitatif & 26 & 0 & 2 & 1 & 0 & 29 \\
\hline Juantitatif & 47 & 4 & 1 & 0 & 1 & 53 \\
\hline Campuran & 1 & 0 & 0 & 0 & 0 & 1 \\
\hline otal & 74 & 4 & 3 & 1 & 1 & 83 \\
\hline
\end{tabular}

Panel B: Metode Penelitian Perpajakan dengan Sumber Disiplin Metode Riset $\quad$ Eko- Psiko-Sosio-Spiritua- Sistem Sumber Disiplin nomi logi logi litas Informasi Total \begin{tabular}{lllllll}
\hline Eksperimen & 1 & 0 & 0 & 0 & 0 & 1 \\
Analisis & 0 & 0 & 0 & 0 & 0 & 0
\end{tabular} $\begin{array}{lcccccc}\text { Analisis } & 0 & 0 & 0 & 0 & 0 & 0 \\ \text { Survei } & 17 & 4 & 1 & 0 & 1 & 23\end{array}$

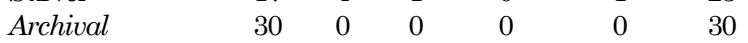
$\begin{array}{lllllll}\text { Kajian Pustaka } & 16 & 0 & 0 & 1 & 0 & 17\end{array}$ $\begin{array}{lllllll}\text { Studi Kasus } & 4 & 0 & 1 & 0 & 0 & 5\end{array}$

$\begin{array}{lllllll}\text { Deskriptif } & 4 & 0 & 0 & 0 & 0 & 4\end{array}$

$\begin{array}{lllllll}\text { Interpretif } & 1 & 0 & 1 & 0 & 0 & 2\end{array}$

\begin{tabular}{lcccccc} 
Fenomenologi & 1 & 0 & 0 & 0 & 0 & 1 \\
\hline Total & 74 & 4 & 3 & 1 & 1 & 72 \\
\hline
\end{tabular}

Tabel 7 menunjukkan sumber disiplin ekonomi mendominasi topik akuntansi keuangan, keperilakuan, lain-lain, dan evaluasi kebijakan. Sumber disiplin psikologi dan sosiologi mendominasi topik keperilakuan. Tabel 8 (lihat lampiran) menunjukkan terdapat 4 artikel (Palil 2004, Latiff dkk 2005, Palil 2005, dan Ibrahim dkk 2003) dengan setting penelitian di luar Indonesia yaitu Malaysia.

Tabel 7. Karakteristik Artikel: Tabulasi Silang Disiplin Sumber dan Topik

\begin{tabular}{lccccc}
\hline $\begin{array}{c}\text { Sumber } \\
\text { Disiplin/Topik }\end{array}$ & \multicolumn{2}{c}{$\begin{array}{c}\text { Akuntansi Evaluasi } \\
\text { Keuangan Kebijakan }\end{array}$} & $\begin{array}{c}\text { Keperi- } \\
\text { lakuan }\end{array}$ & $\begin{array}{c}\text { Lain- } \\
\text { Lain }\end{array}$ & Total \\
\hline Ekonomi & 36 & 10 & 15 & 13 & 74 \\
Psikologi & 0 & 0 & 3 & 1 & 4 \\
Sosiologi & 0 & 0 & 2 & 1 & 3 \\
Spiritualitas & 0 & 0 & 1 & 0 & 1 \\
Sistem Informasi & 0 & 0 & 0 & 1 & 1 \\
\hline \multicolumn{1}{c}{ Total } & 36 & 10 & 21 & 16 & 83 \\
\hline
\end{tabular}

ANALISIS SITASI

Bagian ini merupakan analisis komunitas ilmuwan perpajakan dalam area akuntansi di 
Indonesia dengan menggunakan analisis sitasi (kutipan) yang bersumber dari Google Scholar (seperti Rosenstreich \& Wooliscroft 2009). Analisis kutipan telah digunakan dalam ilmu alam dan sosial untuk tujuan mengevaluasi kontribusi penelitian dari artikel, jurnal, institusi, dan individu (Garfield 1979). Pendekatan analisis sitasi ini melibatkan penentuan frekuensi sebuah artikel yang dikutip oleh penelitian lain. Implikasi yang mendasarinya adalah bahwa semakin sering sebuah artikel dikutip, semakin besar dampak yang dimilikinya di bidangnya (Brown \& Gardner 1985). Keuntungan utama dari sitasi adalah sitasi memberikan ukuran kerja yang objektif dan mudah diukur dari dampak pekerjaan tertentu pada penelitian selanjutnya (Dunbar \& Weber 2014). Penggunaan sitasi untuk mengevaluasi pengaruh penelitian memiliki sejarah panjang (misalnya, Garfield 1972, 1979) dan telah banyak digunakan di banyak disiplin ilmu (misalnya, Kim et al. 2006 dan Arnold et al. 2003 adalah contoh di bidang ekonomi dan keuangan). Dalam akuntansi, Brown \& Gardner (1985), Dyckman \& Zeff (1984), Chan et al. (2009), Oler et al. (2010) dan Dunbar \& Weber (2014). Chan et al. (2009) menggunakan referensi yang dikumpulkan dari disertasi Ph.D. akuntansi untuk menentukan peringkat jurnal akuntansi yang paling berpengaruh. Oler et al. (2010) menggunakan sitasi untuk melacak trend dalam penelitian akuntansi selama periode 19602007. Dunbar \& Weber (2014) menggunakan analisis sitasi untuk mengidentifikasi karya penelitian individual yang sangat berpengaruh pada penelitian akuntansi kontemporer. Dalam perpajakan, Hutchison and White (2003) juga menggunakan analisis sitasi untuk menguji sejauh mana kutipan/sitasi artikel Journal of the American Taxation Association (JATA) di dalam jurnal itu sendiri dan di jurnal akademik dan akuntansi lainnya. Diperkuat beberapa bukti empiris (seperti Bayer \& Folger 1966; Robinson \& Adler 1981) yang menunjukkan jumlah sitasi berkorelasi lebih baik dengan peringkat ahli peneliti daripada jumlah aktual makalah yang diterbitkan, tingkat pendapatan, dan jumlah dan kualitas siswa mereka. Jadi dapat dikatakan salah satu indikator kinerja bagi peneliti adalah meningkatnya jumlah sitasi dari karya yang dihasilkannya.

Bagan 1 menunjukkan distribusi jurnal yang artikel perpajakannya mendapatkan sitasi. Jurnal yang memiliki sitasi tinggi adalah JAK (157 sitasi dari 19 artikel), JAAI (45 sitasi dari 7 artikel), dan JAKI (43 sitasi dari 12 artikel). Sedangkan jurnal EKUITAS merupakan jurnal yang memiliki jumlah artikel terbanyak namun mendapatkan sitasi rendah (6 sitasi dari 17 artikel). Selama 20 tahun, jumlah sitasi dari 7 jurnal nasional terakreditasi mencapai 275 sitasi untuk 41 artikel (49\% dari total 83 artikel perpajakan) dengan jumlah sitasi per artikel berkisar antara 41-1 kali. Namun sayang masih terdapat 38 artikel (46\%) yang tidak mendapatkan sitasi (yaitu Setyaningsih \& Okfitasari 2016, Novita \& Hartadinata 2016, Sudaryono \& Setiawan 2015, Hamzah 2011, Soedjono \& Handayani 2005, Ngumar 2000a, Ngumar 2000b, Ngumar 2000c, Suryono \& Anita 1998, Riduwan 1998, Herlambang 1997, Retnani 1997, Geraldina 2013, Irreza \& Yulianti 2012, Nuryanah \& Christine 2009, Yulianti 2005, Prasetyo 2016, Rusydi \& Djakman 2016, Yuhertiana dkk 2016, Sari \& Lyana 2015, Mutiah dkk 2011, Sumiyana \& Pribadi 2010, Rusydi 2010, Tjondro dkk 2016, Mangoting 2008, Ibrahim dkk 2003, Mangoting 2000b, Saputra dkk 2015, Ratmono 2014, Tarjo \& Kusumawati 2010, Hanna \& Haryanto 2016, Harnovinsah \& Mubarakah 2016, Amilin 2016, Salsabila dkk 2016, Indrawati \& Budiwitaksono 2015, Tiaras \& Wijaya 2015, Iskandar \& Haryanto 2015, Chandra \& Hanna 2015) dan 4 artikel (5\%) yang tidak teridentifikasi sitasinya (yaitu Riduwan 1997, Lasmana dkk 2005, Kariyoto dkk 2012, Salman \& Farid 2010). Hasil penelitian tersebut mirip dengan yang ditemukan di luar negeri oleh Hutchison and White (2003) bahwa dari 308 artikel di Journal of the American Taxation Association (JATA) selama periode 1979-2000 (selama 22 tahun) terdapat 314 kutipan.

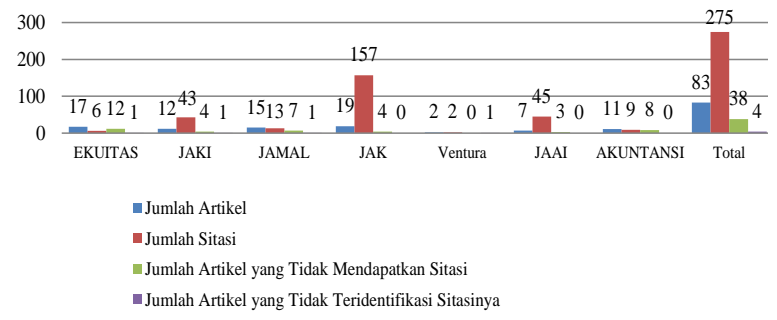

Bagan 1. Distribusi Sitasi Artikel Perpajakan dalam Akuntansi di Indonesia selama 20 Tahun (1997-2016)

Bagan 2 menunjukkan perbandingan distribusi sitasi artikel perpajakan dalam akuntansi di Indonesia selama dua dekade. Nampak dari bagan 2 bahwa sitasi mengalami peningkatan dari 109 sitasi (dekade pertama) menjadi 166 sitasi (dekade kedua). Artikel yang tidak mendapatkan sitasi pada dekade pertama sebanyak 11 artikel dan 27 artikel untuk dekade kedua. Sedangkan yang tidak teridentifikasi nilai sitasinya sebanyak 2 artikel setiap dekade. Bagan 3 menunjukkan rangking 20 penulis artikel perpajakan tertinggi berdasarkan dari jumlah sitasinya. Nampak bahwa dua artikel tertinggi yaitu Mangoting (1999b) mendapatkan jumlah sitasi tertinggi dari 83 artikel yaitu 41 kali dengan topik bahasan akuntansi 
keuangan mengenai perencanaan pajak dengan metode kajian pustaka dan Hidayat dan Nugroho (2010) mendapatkan jumlah sitasi sebanyak 30 kali dengan topik bahasan keperilakuan mengenai ketidakpatuhan wajib pajak dengan metode survei. Untuk lebih rincinya dapat dilihat pada tabel 8 (lihat lampiran) mengenai ranking penulis 83 artikel perpajakan berdasarkan jumlah sitasi.

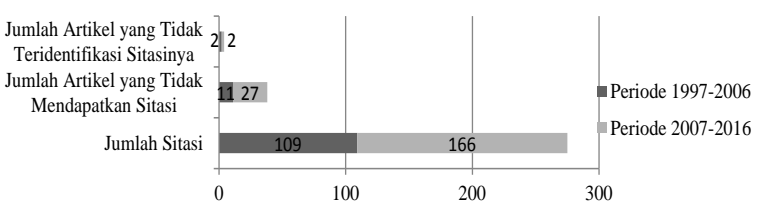

Bagan 2. Perbandingan Distribusi Sitasi Artikel Perpajakan dalam Akuntansi di Indonesia selama Dua Dekade

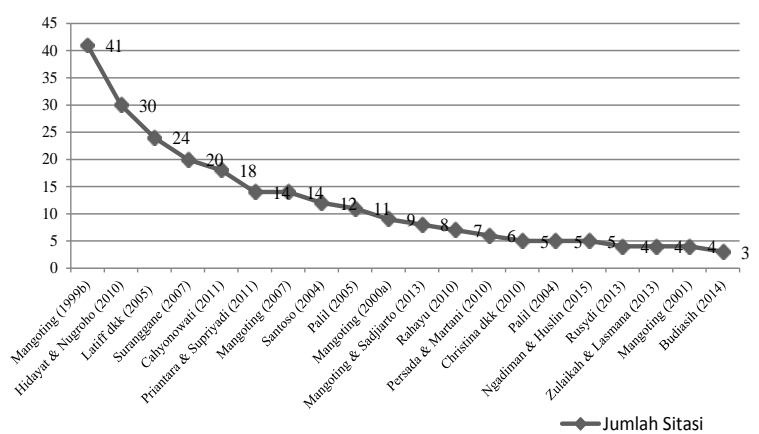

Bagan 3. Dua Puluh Penulis Artikel Perpajakan Tertinggi berdasarkan dari Jumlah Sitasi

Hasil analisis sitasi menunjukkan 49\% artikel perpajakan di Indonesia selama 20 tahun telah mendapatkan sitasi dengan jumlah sitasi per artikel berkisar antara 41-1 kali. Sitasi dapat menjadi salah satu bukti yang objektif dan mudah diukur bahwa hasil karyanya memiliki dampak bagi ilmu yang dikaji oleh peneliti tersebut (Untari 2016; Bayer \& Folger 1966; Robinson \& Adler 1981; Garfield 1972 1979; Kim et al. 2006; Arnold et al. 2003; Brown \& Gardner (1985); Dyckman \& Zeff (1984); Chan et al. (2009); Oler et al. (2010); dan Dunbar \& Weber (2014). Jadi dapat disimpulkan bahwa hampir setengah penelitian perpajakan di Indonesia selama 20 tahun (periode 19972016) telah memiliki dampak bagi ilmu perpajakan dalam akuntansi.

\section{KESIMPULAN DAN SARAN}

Tulisan ini memberikan catatan kecil sejarah perjalanan ilmiah yang telah menghasilkan penelitian akuntansi terkini tentang perpajakan di Indonesia. Tinjauan ini mencerminkan perjuangan penelitian pajak dalam akuntansi selama 20 tahun (periode 1997-2016). Berdasarkan 83 artikel perpajakan-dalam 7 jurnal akreditasi nasional yang tersedia online dan mengkaji bidang akuntansi nampak bahwa tingkat market share artikel perpajakan dari artikel akuntansi di Indonesia masih kecil (hanya sebesar 17\% (83 dari 494 artikel)) dan journal share artikel perpajakan tertinggi ada di 2 dari 3 jurnal yang memberikan tempat kajian penelitian perpajakan yaitu JAK dan jurnal EKUITAS. Trend selama 20 tahun menunjukkan topik perpajakan yang paling banyak diteliti adalah yang berkaitan dengan akuntansi keuangan dan keperilakuan serta metode penelitian kuantitatif merupakan metode yang dominan dalam penelitian perpajakan. Selain itu, metode archival, survei dan kajian pustaka merupakan tiga metode penelitian yang paling dominan dalam penelitian perpajakan selama 20 tahun. Terjadi peningkatan metode kualitatif seperti studi kasus, deskriptif, interpretif dan fenomenologi dalam dua dekade amatan. Sedangkan metode yang mengalami penurunan adalah metode kajian pustaka. Disiplin sumber ekonomi merupakan disiplin sumber yang paling dominan dalam artikel perpajakan.

Karakteristik jurnal menunjukkan bahwa JAKI, EKUITAS, jurnal Akuntansi dan JAAI didominasi dengan topik akuntansi keuangan. Topik evaluasi kebijakan mendominasi di jurnal EKUITAS, JAKI, JAMAL dan JAK. Topik keperilakuan sangat mendominasi di jurnal VENTURA, JAAI, JAMAL, dan jurnal Akuntansi. Semua jurnal didominasi oleh disiplin sumber ekonomi. Analisis sitasi menunjukkan bahwa hampir setengah penelitian perpajakan (49\%) di Indonesia selama 20 tahun telah memiliki dampak bagi ilmu perpajakan dalam akuntansi.

Beberapa implikasi hasil penelitian ini adalah sebagai berikut. Pertama, masih terbuka lebar peluang penelitian perpajakan dalam akuntansi di Indonesia. Misalnya, penelitian keperilakuan dapat diteliti kembali dengan metode kualitatif/ campuran/eksperimen. Penelitian evaluasi kebijakan perpajakan juga masih terbuka untuk diteliti dengan metode campuran. Beberapa isu penelitian perpajakan yang juga belum nampak adalah pajak e-commerce di Indonesia padahal $e$ commerce sedang marak saat ini (sedangkan pajak e-commerce yang terpublikasi dalam salah satu jurnal terkait sistem di Malaysia); aspek perpajakan terkait penyerapan dana desa sesuai dengan Undang Undang Nomor 6 Tahun 2014 tentang Desa; dan dampak konvergensi IFRS terhadap perpajakan. Kedua, penelitian perpajakan masih dapat dikembangkan dengan menggunakan teori selain ekonomi. Hal ini seperti dinyatakan Hanlon (2010) bahwa penelitian pajak di akuntansi membutuhkan lebih banyak teori. Ketiga, analisis sitasi masih menunjukkan $46 \%$ artikel perpajakan tidak mendapatkan sitasi. Hasil tersebut dapat dijadi- 
kan bahan evaluasi kinerja akademisi akuntansi khususnya peneliti perpajakan. Keempat, bagi peneliti yang akan mempublikasikan hasil penelitian perpajakan dalam akuntansi dapat mempertimbangkan temuan terkait topik, metode dan disiplin ilmu yang telah banyak diteliti, serta karakteristik artikel dan jurnal yang ada dalam penelitian ini agar memiliki peluang diterima yang lebih besar.

Penelitian ini memiliki beberapa keterbatasan. Pertama, penelitian ini tidak dapat mengakses secara online salah satu jurnal yang menjadi obyek amatan yaitu jurnal Akuntansi dari periode pertama terbit yaitu tahun 2004 sampai dengan tahun 2014. Hal ini dapat mempengaruhi hasil penelitian dikarenakan jurnal Akuntansi merupakan jurnal yang memberikan ruang kajian perpajakan. Ketidaktersediaan akses secara online juga menyebabkan tidak dapat melakukan analisis sitasi. Kedua, penelitian ini membatasi pembahasan dengan pendekatan bibliografi tentang isu atau topik umum, metode penelitian, disiplin ilmu yang telah dipelajari, penulis yang telah memberi kontribusi pada pengetahuan, jurnal yang telah menerbitkan karya penting di bidang ini dan jumlah sitasi. Penelitian selanjutnya dapat mengembangkan dengan melakukan pemetaan penelitian perpajakan dengan melihat dari sisi substansi penelitian seperti variabel penelitian yang digunakan, teori penelitian, dan hasil penelitian. Ketiga, penelitian ini mengacu pada kerangka penelitian Hesford et al. (2007). Penelitian selanjutnya dapat mengembangkannya dengan beberapa kerangka penelitian seperti Hackelford and Shevlin (2001), Shevlin (2007), Hanlon and Heitzman (2010). Keempat, penelitian ini menggunakan analisis sitasi untuk mengukur dampak penelitian perpajakan dalam akuntansi karena pertimbangan ketersediaan data. Meskipun beberapa hasil penelitian sebelumnya (seperti Bayer \& Folger 1966; Robinson \& Adler 1981) telah membuktikan secara empiris bahwa jumlah sitasi berkorelasi lebih baik dengan peringkat ahli peneliti daripada ukuran yang lain, bagaimanapun analisis sitasi adalah ukuran pengaruh yang tidak sempurna (Dunbar \& Weber 2014). Dunbar \& Weber (2014) memberikan beberapa contoh ketidaksempurnaan sitasi seperti: 1) jumlah kutipan dapat dipengaruhi oleh self-citations ala kadarnya atau referensi negatif pada karya asli. 2) Sitasi juga bisa menjadi hasil dari perilaku strategis, seperti "efek halo", dimana penulis mencoba untuk melegitimasi makalah mereka dengan mengutip periset terkenal. 3) Penulis mungkin juga secara strategis mengutip penelitian sebelumnya dalam upaya untuk mempengaruhi proses peninjauan (misalnya, untuk mempengaruhi pemilihan peng- ulas potensial atau untuk menyanjung editor). Oleh karenanya, penelitian selanjutnya dapat menggunakan alat ukur lain sebagai pembanding hasil analisis sitasi.

\section{DAFTAR PUSTAKA}

Adhikari, Ajay; Tondkar, Rasoul H.; and Hora, Judith A. 2002. An Analysis of International Accounting Research in Journal of International Accounting Auditing \& Taxation: 19922001. Journal of International Accounting, Auditing \& Taxation, 11: 39-49.

Al Irsyad, Rahmatusifa dan Martani, Dwi. 2013. Analisis Publikasi Artikel pada Jurnal The Accounting Review, Journal of Accounting and Economics, dan Journal of Accounting Research Tahun 2008-2012. Prosiding Simposium Nasional Akuntansi XVI yang diselenggarakan oleh Universitas Sam Ratulangi.

Amilin, Amilin. 2016. Peran Konseling, Pengawan dan Pemeriksaan oleh Petugas Pajak dalam Mendorong Kepatuhan Wajib Pajak dan Dampaknya terhadap Penerimaan Negara. Jurnal Akuntansi, 20(2): 285-300.

Arnold, T., A. Butler, T. F. Crack, and A. Altintig. 2003. Impact: What Influences Finance Research? Journal of Business, 76: 343-361.

Astuti, Titiek Puji dan Aryani, Y Anni. 2016. Tren Penghindaran Pajak Perusahaan Manufaktur di Indonesia yang Terdaftar di BEI Tahun 2001-2014. Jurnal Akuntansi, 20(3): 375-388.

Bayer, A. E., and Folger, J. 1966. Some Correlates of a Citation Measure of Productivity in Science. Sociology of Education, 39: 383-390.

Bonner, SE.; Hesford, J.W., Van der Stede, W.A. and Young, S. M. 2006. The Most Influential Journals in Academic Accounting. Accounting, Organizations and Society, 31: 663-685.

Brown, Lawrence D. and Gardner, John C. 1985. Using Citation Analysis to Assess the Impact of Journals and Articles on Contemporary Accounting Research (CAR). Journal of Accounting Research, 23(1): 84-109.

Budiasih, I Gusti Ayu Nyoman. 2014. Fenomena Akuntabilitas Perpajakan pada Jaman Bali Kuno: Suatu Studi Interpretatif. Jurnal Akuntansi Multiparadigma, 5(3): 409-420.

Cahyonowati, Nur. 2011. Model Moral dan Kepatuhan Perpajakan: Wajib Pajak Orang Pribadi. Jurnal Akuntansi dan Auditing Indonesia, 15(2): 161-177.

Cahyonowati, Nur; Ratmono, Dwi; dan Faisal, Faisal. 2012. Peranan Etika, Pemeriksanaan, dan Denda Pajak untuk Meningkatkan Kepatuhan Wajib Pajak Orang Pribadi. Jurnal Akuntansi Keuangan Indonesia, 9(2): 136-153. 
Chan, K., K. Chan, G. Seow, and K. Tam. 2009. Ranking Accounting Journals Using Dissertation Citation Analysis: A Research Note. Accounting, Organizations and Society, 34: 875-885.

Chandra, Cerelia dan Hanna, Hanna. 2015. Pengaruh Manajemen Laba dan Perbedaan Pembukuan Menurut Pajak dan Akuntansi terhadap Peringkat Obligasi. Jurnal Akuntansi, 19(2): 260-275.

Coyne, J.G.; Summers, S.L; Williams, B., and Wood, D.A. 2010. Accounting Program Research Ranking by Topical Area and Methodology. Accounting Education, 25: 631-654.

Darmayasa, I Nyoman; dan Aneswari, Yuyung Rizka. 2016. The Role of Local Wisdom to Tax Compliance. Jurnal Akuntansi Multiparadigma, 7(1): 110-119.

Deslatu, Shella; dan Susanto, Yulius Kurnia. 2010. Pengaruh Kepemilikan Managerial, Debt Covenant, Litigation, Tax and Political Costs dan Kesempatan Bertumbuh terhadap Konservatisma Akuntansi. Ekuitas Jurnal Ekonomi dan Keuangan, 14(2): 137-151.

Diamastuti, Erlina. 2016. Ke(tidak)patuhan Wajib Pajak: Potret Self Assessment System. Ekuitas Jurnal Ekonomi dan Keuangan, 20(3): 280-304.

Dunbar, Amy E., and Weber, David P. 2014. What Influences Accounting Research? A CitationsBased Analysis. Issues in Accounting Education, 29(1): 1-60.

Dyckman, T. R. and Zeff, S. A. 1984. Two Decades of the Journal of Accounting Research. Journal of Accounting Research: 225-297.

Dykxhoorn, Hans J. and Sinning, Kathleen E. 2010. A Review and Analysis of International Accounting Research in JIAAT: 2002-2010. Journal of International Accounting, Auditing and Taxation, 19: 137-153.

Fasmi, Lasnofa; dan Misra, Fauzan. 2014. Modernisasi Sistem Administrasi Perpajakan dan Tingkat Kepatuhan Pengusaha Kena Pajak. Jurnal Akuntansi Multiparadigma, 5(1): 7687.

Fidiana, Fidiana. 2015. Kepatuhan Pajak dalam Perspektif Neo Ashabiyah. Ekuitas Jurnal Ekonomi dan Keuangan, 19(2): 260-75.

Garfield, E. 1972. Citation Analysis as a Tool in Journal Evaluation. Science, 178: 471-479.

Garfield, E. 1979. Is Citation Analysis a Legitimate Evaluation Tool? Scientometrics, 1: 359-375.

Geraldina, Ira. 2013. Preferensi Manajemen Laba Akrual atau Manajemen Laba Riil dalam Aktivitas Tax Shelter. Jurnal Akuntansi Keuangan Indonesia, 10(2): 206-224.
Graham, J.R., 2011. A Summary of Recent Corporate Tax Research. NBER Reporter (4):5.

Hamzah, Ardi. 2011. Daya Prediksi Pajak, Laba dan Arus Kas terhadap Pajak Masa Depan pada Perusahaan Manufaktur di Bursa Efek Indonesia. Ekuitas Jurnal Ekonomi dan Keuangan, 15(3): 291-306.

Hanlon, Michelle and Heitzman, Shane. 2010. A Review of Tax Research. Journal of Accounting and Economics, 50: 127-178.

Hanna, Hanna dan Haryanto, Melinda. 2016. Agresivitas Pelaporan Keuangan, Agresivitas Pajak, Tata Kelola Perusahaan dan Kepemilikan Keluarga. Jurnal Akuntansi, 20(3): 407-419.

Harnovinsah, Harnovinsah dan Mubarakah, Septyana. 2016. Dampak Accounting Choices terhadap Tax Aggressive. Jurnal Akuntansi, 20(2): 267-284.

Herlambang, Yudha. 1997. Making Social Welfair Through National Tax System Efficiency in Indonesia. Ekuitas Jurnal Ekonomi dan Keuangan, 1(3): 150-157.

Hesford, James W.; Lee, Sung-Han (Sam); Der Stede, Wim A. Van; and Young, S. Mark. 2007. Management Accounting: A Bibliographic Study. Handbook of Management Accounting Research: 3-26.

Hidayat, Widi; dan Nugroho, Argo Adhi. 2010. Studi Empiris Theory of Planned Behavior dan Pengaruh Kewajiban Moral pada Perilaku Ketidakpatuhan Pajak Wajib Pajak Orang Pribadi. Jurnal Akuntansi dan Keuangan, 12(2): 82-93.

Hutchison, Paul D. and White, Craig G. 2003. The Journal of the American Taxation Association 1979-2000: Content, Participation, and Citation Analyses. The Journal of the American Taxation Association, 25(1): 100-121.

Ibrahim, Daing Nasir; Yuskar, Yuskar; dan Taib, Fauziah Md. 2003. Manajemen Pendapatan dan Pengecualian Pajak Pendapatan di Malaysia. Jurnal Akuntansi dan Keuangan, 5(2): 91-109.

Indrawati, Indrawati dan Budiwitaksono, Gideon Setyo. 2015. Studi Faktor-Faktor Pemotivasi Manajemen Melakukan Tax Planning. Jurnal Akuntansi, 19(3): 370-379.

Irreza Irreza, Yulianti Yulianti. 2012. Penggunaan Komponen Pembentuk Pajak Tangguhan dalam Mendeteksi Manajemen Laba. Jurnal Akuntansi Keuangan Indonesia, 9(1): 68-82.

Iskandar, Angelina Tiffany dan Haryanto, Melinda. 2015. The Influence of Implicit Tax in Making Profitable Foreign Direct Investment Decisions: Evidence of Indonesian Listed Companies in All Sectors. Jurnal Akuntansi, 19(2): 192-206. 
Kariyoto; Subroto, Bambang; Sutrisno dan Rosidi. 2012. Pengaruh Kesadaran dan Kepatuhan Wajib Pajak terhadap Kinerja Perpajakan (Studi pada Kanwil Ditjen Pajak Jawa Timur III). Jurnal Akuntansi Multiparadigma, 3(1): 62-76.

Kartikasari, Sabrina; dan Lasmana, Mienati Somya. 2013. Pengaruh Kebijakan Dividen terhadap Kepemilikan Individual dan Kepemilikan Institusional dengan Perubahan Peraturan Perpajakan sebagai Variabel Pemoderasi. Jurnal Akuntansi dan Keuangan, 15(1): 51-62.

Kim, E. H., A. Morse, and L. Zingales. 2006. What has Mattered to Economics since 1970? Journal of Economic Perspectives, 20: 189-202.

Lasmana, Mienati Somya; Narsa, I Made; dan Sawarjuwono, Tjiptohadi. 2005. Pengaruh Penerapan Sistem Monitoring Pelaporan Pembayaran Pajak (MP3) terhadap Tingkat Kepatuhan Wajib Pajak (Studi Empiris pada Kantor Wilayah Direktorat Jenderal Pajak Jawa Bagian Timur I). Jurnal Akuntansi Keuangan Indonesia, 2(1): 130-158.

Latiff, Ahmed Razman Abdul; Noordin, Bany Ariffin Amin; Omar, Mohamad Raflis Che; dan Harjito, Dwipraptono Agus. 2005. Tax Literacy Rate Among Taxpayers: Evidence from Malaysia. Jurnal Akuntansi dan Auditing Indonesia, 9(1): 1-11.

Mangoting, Yenni. 1999a. Penggunaan Metode by Purchase dan Pooling of Interest dalam Rangka Penggabungan Usaha (Business Combination) dan Efeknya terhadap Pajak Penghasilan. Jurnal Akuntansi dan Keuangan, 1(2): 132-143.

Mangoting, Yenni. 1999b. Tax Planning: Sebuah Pengantar sebagai Alternatif Meminimalkan Pajak. Jurnal Akuntansi dan Keuangan, 1(1): 43-53.

Mangoting, Yenni. 2000a. Aspek Perpajakan dalam Praktek Transfer Pricing. Jurnal Akuntansi dan Keuangan, 2(1): 69-82.

Mangoting, Yenni. 2000b. Menyongsong Tax Reform 2001: Khusus Pajak Penghasilan. Jurnal Akuntansi dan Keuangan, 2(2): 116126.

Mangoting, Yenni. 2001. Pajak Penghasilan dalam Sebuah Kebijaksanaan. Jurnal Akuntansi dan Keuangan, 3(2): 142-156.

Mangoting, Yenni. 2003. Tinjauan Aspek Pajak Penghasilan atas Transaksi Instrumen Keuangan Derivatif SWAP. Jurnal Akuntansi dan Keuangan, 5(1): 75-90.

Mangoting, Yenni. 2007. Biaya Tanggung Jawab Sosial sebagai Tax Benefit. Jurnal Akuntansi dan Keuangan, 9(1): 35-42.
Mangoting, Yenni. 2008. Mengapa Perlu Menghapus SPT Tahunan 1721? Jurnal Akuntansi dan Keuangan, 10(2): 109-120.

Mangoting, Yenni; dan Sadjiarto, Arja. 2013. Pengaruh Postur Motivasi terhadap Kepatuhan Wajib Pajak Orang Pribadi. Jurnal Akuntansi dan Keuangan, 15(2): 106-116.

Marfuah, M; dan Azizah, Andri Puren N. 2014. Pengaruh Pajak, Tunneling Incentive dan Exchange Rate pada Keputusan Transfer Pricing Perusahaan. Jurnal Akuntansi dan Auditing Indonesia, 18(2): 156-165.

Maydew, Edward L. 2001. Empirical Tax Research in Accounting: A Discussion. Journal of Accounting and Economics, 31: 389-403.

Mutiah, Mutiara; Harwida, Gita Arasy dan Kurniawan, Fitri Ahmad. 2011. Interpretasi Pajak dan Implikasinya menurut Perspektif Wajib Pajak Usaha Mikro, Kecil dan Menengah. Jurnal Akuntansi Multiparadigma (JAMAL), 2(3): 418-429.

Ngadiman, Ngadiman dan Huslin, Daniel. 2015. Pengaruh Sunset Policy, Tax Amnesty, dan Sanksi Pajak terhadap Kepatuhan Wajib Pajak (Studi Empiris di Kantor Pelayanan Pajak Pratama Jakarta Kembangan). Jurnal Akuntansi, 19(2): 225-241.

Ngumar, Sutjipto. 2000a. Penerapan Akuntansi Perpajakan di Indonesia. Ekuitas Jurnal Ekonomi dan Keuangan, 14(4): 204-217.

Ngumar, Sutjipto. 2000b. Peranan Akuntansi dalam Perpajakan di Indonesia. Ekuitas Jurnal Ekonomi dan Keuangan, 14(3): 129-138.

Ngumar, Sutjipto. 2000c. Tax Planning untuk Pembayaran Pajak dengan Benar bagi Perusahaan di Indonesia. Ekuitas Jurnal Ekonomi dan Keuangan, 14(1): 43-54.

Novita, S; dan Hartadinata, Okta S. 2016. Pendidikan Perpajakan: Persepsi Akademisi, Praktisi, dan Mahasiswa untuk Jenjang Diploma dan Sarjana. Ekuitas Jurnal Ekonomi dan Keuangan, 20(2): 151-171.

Nuryanah, Siti; dan Christine, Christine. 2009. Income Tax Gap: Kajian Deskriptif dan Empiris atas Koreksi Pajak di Indonesia. Jurnal Akuntansi Keuangan Indonesia, 6(2): 221-244.

Oktavia, Oktavia; dan Martani, Dwi. 2013. Tingkat Pengungkapan dan Penggunaan Derivatif Keuangan dalam Aktivitas Penghindaran Pajak. Jurnal Akuntansi Keuangan Indonesia, 10(2): 129-146.

Oler, D.; Oler,M.; and Skousen, C. 2010. Characterizing Accounting Research. Accounting Horizons, 24: 635-670.

Palil, Mohd Rizal. 2004. The Effect of E-Commerce on Malaysian Tax System: An Empirical 
Evidance from Academicians and Malaysian Tax Practitioners. Jurnal Akuntansi dan Keuangan, 6(1): 1-9.

Palil, Mohd Rizal. 2005. Taxpayers Knowledge: A Descriptive Evidence on Demographic Factors in Malaysia. Jurnal Akuntansi dan Keuangan, 7(1): 11-21.

Persada, Aulia Eka; dan Martani, Dwi. 2010. Analisis Faktor yang Mempengaruhi Book Tax Gap dan Pengaruhnya terhadap Persistensi Laba. Jurnal Akuntansi Keuangan Indonesia, 7(2): 205-221.

Prasetyo, Whedy. 2016. Menjamin Kepatuhan Wajib Pajak melalui Penerbitan Surat Tagihan Pajak. Jurnal Akuntansi Multiparadigma, 7(3).

Priantara, Diaz; dan Supriyadi, Bambang. 2011. Faktor-Faktor yang Mempengaruhi Pengusaha Kecil dan Mikro Mendaftar Menjadi Wajib Pajak Orang Pribadi. Jurnal Akuntansi dan Keuangan, 13(2): 105-118.

Rachmawati, Nurul Aisyah; dan Martani, Dwi. 2014. Pengaruh Large Positive Abnormal Book-Tax Differences terhadap Persistensi Laba. Jurnal Akuntansi Keuangan Indonesia, 11(2): 120-137.

Rahayu, Ning. 2010. Evaluasi Regulasi atas Praktik Penghindaran Pajak Penanaman Modal Asing. Jurnal Akuntansi Keuangan Indonesia, 7(1): 61-78.

Ratmono, Dwi. 2014. Model Kepatuhan Perpajakan Sukarela: Peran Denda, Keadilan Prosedural, dan Kepercayaan terhadap Otoritas Pajak. Jurnal Akuntansi dan Auditing Indonesia, 18(1): 42-64.

Ratnafuri, Kiki dan Herawati, Nurul. 2012. Malpraktek Pemotongan dan Pemunggutan Pajak oleh Bendaharawan Pemerintah. Jurnal Akuntansi Multiparadigma, 3(3): 471492.

Retnani, Endang Dwi. 1997. Penerapan Akuntansi Perpajakan di Indonesia. Ekuitas Jurnal Ekonomi dan Keuangan, 1(1): 70-78.

Riduwan, Akhmad. 1997. Akuntansi Pajak Pertambahan Nilai dan Pajak Penjualan Barang Mewah. Ekuitas Jurnal Ekonomi dan Keuangan, 15(3): 1-15.

Riduwan, Akhmad. 1998. Akuntansi Pajak Penghasilan (Pernyataan Standar Akuntansi Keuangan No. 46). Ekuitas Jurnal Ekonomi dan Keuangan, 2(4): 206-225.

Robinson, L. M., and Adler, R. 1981. Measuring the Impact of Marketing Scholars and Institutions: An Analysis of Citation Frequency. Journal of the Academy of Marketing Science, 147-162.

Rosenstreich, Daniela and Wooliscroft, Ben. 2009. Measuring the Impact of Accounting Journals using Google Scholar and the G-Index. The British Accounting Review, 41: 227-239.

Rusydi, M Khoiru; dan Djakman, Chaerul D. 2016. Pengaruh Book-Tax Differences terhadap Investor Trading. Jurnal Akuntansi Multiparadigma, 7(1): 101-109.

Rusydi, M. Khoiru. 2010. Analisis Pengaruh Perubahan Peraturan Perpajakan pada Sektor Usaha Jasa Konstruksi di Indonesia. Jurnal Akuntansi Multiparadigma, 1(3): 437-447.

Rusydi, M. Khoiru. 2013. Pengaruh Ukuran Perusahaan terhadap Aggressive Tax Avoidance di Indonesia. Jurnal Akuntansi Multiparadigma, 4(2): 322-329.

Sadjiarto, Arja. 2008. Variasi Penghitungan dan Penyetoran Pajak Penghasilan Pasal 21. Jurnal Akuntansi dan Keuangan, 10(1): 4868.

Salman, Kautsar Riza; dan Farid, Mochammad. 2010. Study of The Taxpayers Compliance in Banking Industries in Surabaya. Journal of Economics, Business, \& Accountancy VENTURA, 13(1): 59-76.

Salman, Kautsar Riza; dan Sarjono, Bayu. 2013. Intention and Behavior of Tax Payment Compliance by The Individual Tax Payers Listed in Pratama Tax Office West Sidoarjo Regency. Journal of Economics, Business, \& Accountancy VENTURA, 16(2): 309-324.

Salsabila, Azzahra; Pratomo, Dudi; dan Nurbaiti, Annisa. 2016. Pengaruh Book Tax Differences dan Aliran Kas Operasi terhadap Persistensi Laba. Jurnal Akuntansi, 20(2): 314-329.

Sandy, Syeldila; dan Lukviarman, Niki. 2015. Pengaruh Corporate Governance terhadap Tax Avoidance: Studi Empiris pada Perusahaan Manufaktur. Jurnal Akuntansi dan Auditing Indonesia, 19(2): 85-98.

Santoso, Iman. 2004. Advance Pricing Agreement dan Problematika Transfer Pricing dari Perspektif Perpajakan Indonesia. Jurnal Akuntansi dan Keuangan, 6(2): 123-139.

Saputra, Muhammad Fajri; Rifa, Dandes dan Rahmawati, Novia. 2015. Pengaruh Corporate Governance, Profitabilitas dan Karakter Eksekutif terhadap Tax Avoidance pada Perusahaan yang Terdaftar di BEI. Jurnal Akuntansi dan Auditing Indonesia, 19(1): 112.

Sari, Diana; dan Lyana, Ina Desna Dwi. 2015. Book Tax Differences dan Kualitas Laba. Jurnal Akuntansi Multiparadigma, 6(3): 399-411.

Setyaningsih, Titik dan Okfitasari, Antin. 2016. Mengapa Wajib Pajak Mengikuti Tax Amnesti (Studi Kasus di Solo). Ekuitas Jurnal Ekonomi dan Keuangan, 20(4): 415-433. 
Shackelford, Douglas A. and Shevlin, Terry. 2001. Empirical Tax Research in Accounting. Journal of Accounting and Economics, 31: 321387.

Shevlin, Terry. 2007. The Future of Tax Research: From an Accounting Professor's Perspective. The Journal of the American Taxation Association (JATA), 29(2): 87-93.

Shields, M. D. 1997. Research in Management Accounting by North Americans in The 1990s. Journal of Management Accounting Research, 9: 3-61.

Siringoringo, Whereson. 2015. Pengaruh Penerapan Good Governance dan Whistleblowing System terhadap Kepatuhan Wajib Pajak Orang Pribadi dengan Resiko Sanksi Pajak sebagai Variabel Moderating Studi Empiris terhadap Wajib Pajak Orang Pribadi di Kota Bekasi. Jurnal Akuntansi, 19(2): 207-224.

Soedjono, Soedjono; dan Handayani, Nur. 2005. Efektifitas Pelaksanaan Peraturan Daerah tentang Retribusi/Iuran Pasar Daerah di Kota Surabaya. Ekuitas Jurnal Ekonomi dan Keuangan, 9(3): 394-417.

Sudaryono, Eko Arief; dan Setiawan, Doddy. 2015. Manajemen Laba dan Penerapan UU No. 36/2008 tentang Perubahan Penghitungan Pajak Penghasilan. Ekuitas Jurnal Ekonomi dan Keuangan, 19(4): 443-460.

Sugiono, Agus; Ludigdo, Unti; dan Baridwan, Zaki. 2015 Makna Pajak dan Retribusi Perspektif Wajib Pajak Kaki Lima. Jurnal Akuntansi Multiparadigma, 6(1): 53-78.

Sumiyana; dan Pribadi, Angelia. 2010. Keberterimaan Situs Pajak: Pengindustrian Orientasi Tujuan Pembelajaran dan Norma Subjektif. Jurnal Akuntansi Multiparadigma, 1(3): 471-492.

Suranggane, Zulaikha. 2007. Analisis Aktiva Pajak Tangguhan dan Akrual sebagai Prediktor Manajemen Laba: Kajian Empiris pada Perusahaan Manufaktur yang Terdaftar di BEJ. Jurnal Akuntansi Keuangan Indonesia, 4(1): 77-94.

Suryono, Bambang, dan Anita, Anita. 1998. Tingkat Pemahaman Wajib Pajak terhadap Undang-Undang No. 10/1994. Ekuitas Jurnal Ekonomi dan Keuangan, 12(4): 175-196.
Syakura, Muhammad Abadan; dan Baridwan, Zaki. 2014. Determinan Perencanaan Pajak dan Perilaku Kepatuhan Wajib Pajak Badan. Jurnal Akuntansi Multiparadigma, 5(2): 185-201.

Syanthi, Nila Trisna Trisna; Sudarma, Made; dan Saraswati, Erwin. 2013. Dampak Manajemen Laba terhadap Perencanaan Pajak dan Persistensi Laba. Ekuitas Jurnal Ekonomi dan Keuangan, 17(2): 192-210.

Tarjo, Tarjo; dan Kusumawati, Indra. 2010. Analisis Perilaku Wajib Pajak Orang Pribadi terhadap Pelaksanaan Self Assessment System: Suatu Studi di Bangkalan. Jurnal Akuntansi dan Auditing Indonesia, 10(1): 101-120.

Tiaras, Irvan dan Wijaya, Henryanto. 2015. Pengaruh Likuiditas, Leverage, Manajemen Laba, Komisaris Independen dan Ukuran Perusahaan terhadap Agresivitas Pajak. Jurnal Akuntansi, 19(3): 380-397.

Tjondro, Elisa; Widuri, Retnaningtyas; dan Katopo, Jacqueline Maria. 2016. Kualitas Corporate Social Responsibility dan Penghindaran Pajak dengan Kinerja Laba sebagai Moderator. Jurnal Akuntansi dan Keuangan, 18(2): 105118.

Untari, Dwi. 2016. Peran Pustakawan dalam Meningkatkan Sitasi Publikasi di Pusat Penelitian Ekonomi LIPI. Kumpulan Makalah Seminar dan Knowledge Sharing Kepustakawan: Kontribusi Pustakawan Berbasis Kajian dan Standar dalam Forum Perpusdokinfo LPNK Ristek - Jakarta, 30 Maret 2016.

Vinna Christina, Yulianti Abbas, Christine Tjen. 2010. Pengaruh Book-Tax Differences terhadap Peringat Obligasi di Indonesia. Jurnal Akuntansi Keuangan Indonesia, 7(2): 153169.

Yuhertiana, Indrawati. 2016. Etika, Organisasi dan Kepatuhan Wajib Pajak. Jurnal Akuntansi Multiparadigma, 7(1): 131-141.

Yulianti, Yulianti. 2005. Kemampuan Beban Pajak Tangguhan dalam Mendeteksi Manajemen Laba. Jurnal Akuntansi Keuangan Indonesia, 2(1):107-129.

Zulaikah, Ninik dan Lasmana, Mienati Somya. 2013. Kepemilikan Manajerial, Kebijakan Pembayaran Dividen dan Efek Moderasi Penurunan Tarif PPh Dividen WP OP Dalam Negeri. Jurnal Akuntansi dan Keuangan, 15(2): 95-105. 


\section{Lampiran:}

Tabel 8. Sampel Penelitian \& Ranking Penulis 83 Artikel Perpajakan berdasarkan Jumlah Sitasi

\begin{tabular}{|c|c|c|c|c|}
\hline $\begin{array}{c}\text { Rangking } \\
\text { berdasarkan } \\
\text { Jumlah Sitasi }\end{array}$ & Penulis & Jurnal & Judul & Sitasi \\
\hline 1 & Mangoting (1999b) & JAK & $\begin{array}{l}\text { Tax Planning: Sebuah Pengantar sebagai Alternatif } \\
\text { Meminimalkan Pajak }\end{array}$ & 41 \\
\hline 2 & $\begin{array}{l}\text { Hidayat \& Nugroho } \\
(2010)\end{array}$ & JAK & $\begin{array}{l}\text { Studi Empiris Theory of Planned Behavioral dan Pengaruh } \\
\text { Kewajiban Moral pada Perilaku Ketidakpatuhan Pajak Wajib } \\
\text { Pajak Orang Pribadi }\end{array}$ & 30 \\
\hline 3 & Latiff dkk (2005) & JAAI & Tax Literacy Rate Among Taxpayers: Evidance from Malaysia* & 24 \\
\hline 4 & Suranggane (2007) & JAKI & $\begin{array}{l}\text { Analisis Aktiva Pajak Tangguhan dan Akrual sebagai Prediktor } \\
\text { Manajemen Laba: Kajian Empiris pada Perusahaan Manufaktur } \\
\text { yang Terdaftar di BEJ }\end{array}$ & 20 \\
\hline 5 & Cahyonowati (2011) & JAAI & $\begin{array}{l}\text { Model Moral dan Kepatuhan Perpajakan: Wajib Pajak Orang } \\
\text { Pribadi }\end{array}$ & 18 \\
\hline 6 & $\begin{array}{l}\text { Priantara \& Supriyadi } \\
\text { (2011) }\end{array}$ & JAK & $\begin{array}{l}\text { Faktor-Faktor yang Mempengaruhi Pengusaha Kecil dan Mikro } \\
\text { Mendaftar Menjadi Wajib Pajak Orang Pribadi }\end{array}$ & 14 \\
\hline 7 & Mangoting (2007) & JAK & Biaya Tanggung Jawab Sosial sebagai Tax Benefit & 14 \\
\hline 8 & Santoso (2004) & JAK & $\begin{array}{l}\text { Advance Pricing Agreement dan Problematika Transfer Pricing } \\
\text { dari Perspektif Perpajakan Indonesia }\end{array}$ & 12 \\
\hline 9 & Palil (2005) & JAK & $\begin{array}{l}\text { Taxpayers Knowledge: A Descriptive Evidence on Demographic } \\
\text { Faktors in Malaysia* }\end{array}$ & 11 \\
\hline 10 & Mangoting (2000a) & JAK & Aspek Perpajakan dalam Praktek Transfer Pricing & 9 \\
\hline 11 & $\begin{array}{l}\text { Mangoting \& Sadjiarto } \\
\text { (2013) }\end{array}$ & JAK & $\begin{array}{l}\text { Pengaruh Postur Motivasi terhadap Kepatuhan Wajib Pajak } \\
\text { Orang Pribadi }\end{array}$ & 8 \\
\hline 12 & Rahayu (2010) & JAKI & $\begin{array}{l}\text { Evaluasi Regulasi atas Praktik Penghindaran Pajak Penanaman } \\
\text { Modal Asing }\end{array}$ & 7 \\
\hline 13 & $\begin{array}{l}\text { Persada \& Martani } \\
\text { (2010) }\end{array}$ & JAKI & $\begin{array}{l}\text { Analisis Faktor yang Mempengaruhi Book Tax Gap dan } \\
\text { Pengaruhnya terhadap Persistensi Laba }\end{array}$ & 6 \\
\hline 14 & Christina dkk (2010) & JAKI & $\begin{array}{l}\text { Pengaruh Book-Tax Differences terhadap Peringkat Obligasi di } \\
\text { Indonesia }\end{array}$ & 5 \\
\hline 15 & Palil (2004) & JAK & $\begin{array}{l}\text { The Effect of E-Commerce on Malaysian Tax System: An } \\
\text { Empirical Evidance from Academicians and Malaysian Tax } \\
\text { Practitioners* }\end{array}$ & 5 \\
\hline 16 & $\begin{array}{l}\text { Ngadiman \& Huslin } \\
\text { (2015) }\end{array}$ & $\begin{array}{l}\text { Jurnal } \\
\text { Akuntansi }\end{array}$ & $\begin{array}{l}\text { Pengaruh Sunset Policy, Tax Amnesty, dan Sanksi Pajak } \\
\text { terhadap Kepatuhan Wajib Pajak (Studi Empiris di Kantor } \\
\text { Pelayanan Pajak Pratama Jakarta Kembangan) }\end{array}$ & 5 \\
\hline 17 & Rusydi (2013) & JAMAL & $\begin{array}{l}\text { Pengaruh Ukuran Perusahaan terhadap Aggressive Tax } \\
\text { Avoidance di Indonesia }\end{array}$ & 4 \\
\hline 18 & $\begin{array}{l}\text { Zulaikah \& Lasmana } \\
\text { (2013) }\end{array}$ & JAK & $\begin{array}{l}\text { Kepemilikan Manajerial, Kebijakan Pembayaran Dividen dan } \\
\text { Efek Moderasi Penurunan Tarif PPh Dividen WPOP Dalam } \\
\text { Negeri }\end{array}$ & 4 \\
\hline 19 & Mangoting (2001) & JAK & Pajak Penghasilan dalam Sebuah Kebijaksanaan & 4 \\
\hline 20 & Budiasih (2014) & JAMAL & $\begin{array}{l}\text { Fenomena Akuntabilitas Perpajakan pada Jaman Bali Kuno: } \\
\text { Suatu Studi Interpretatif }\end{array}$ & 3 \\
\hline 21 & Fidiana (2015) & EKUITAS & Kepatuhan Pajak dalam Perspektif Neo Ashabiyah & 2 \\
\hline 22 & $\begin{array}{l}\text { Deslatu \& Susanto } \\
(2010)\end{array}$ & EKUITAS & $\begin{array}{l}\text { Pengaruh Kepemilikan Managerial, Debt Covenant, Litigation, } \\
\text { Tax and Political Costs dan Kesempatan Bertumbuh terhadap } \\
\text { Konservatisma Akuntansi }\end{array}$ & 2 \\
\hline 23 & $\begin{array}{l}\text { Oktavia \& Martani } \\
\text { (2013) }\end{array}$ & JAKI & $\begin{array}{l}\text { Tingkat Pengungkapan dan Penggunaan Derivatif Keuangan } \\
\text { dalam Aktivitas Penghindaran Pajak }\end{array}$ & 2 \\
\hline 24 & Cahyonowati dkk (2012) & JAKI & $\begin{array}{l}\text { Peranan Etika, Pemeriksanaan, dan Denda Pajak untuk } \\
\text { Meningkatkan Kepatuhan Wajib Pajak Orang Pribadi }\end{array}$ & 2 \\
\hline 25 & $\begin{array}{l}\text { Syakura \& Baridwan } \\
\text { (2014) }\end{array}$ & JAMAL & $\begin{array}{l}\text { Determinan Perencanaan Pajak dan Perilaku Kepatuhan Wajib } \\
\text { Pajak Badan }\end{array}$ & 2 \\
\hline 26 & Mangoting (1999a) & JAK & $\begin{array}{l}\text { Penggunaan Metode By Purchase dan Pooling of Interest dalam } \\
\text { Rangka Penggabungan Usaha (Business Combination) dan } \\
\text { Efeknya terhadap Pajak Penghasilan }\end{array}$ & 2 \\
\hline 27 & $\begin{array}{l}\text { Salman \& Sarjono } \\
\text { (2013) }\end{array}$ & Ventura & $\begin{array}{l}\text { Intention and Behavior of Tax Payment Compliance by The } \\
\text { Individual Tax Payers Listed in Pratama Tax Office West } \\
\text { Sidoarjo Regency }\end{array}$ & 2 \\
\hline 28 & $\begin{array}{l}\text { Sandy \& Lukviarman } \\
\text { (2015) }\end{array}$ & JAAI & $\begin{array}{l}\text { Pengaruh Corporate Governance terhadap Tax Avoidance: Studi } \\
\text { Empiris pada Perusahaan Manufaktur }\end{array}$ & 2 \\
\hline 29 & Astuti \& Aryani (2016) & $\begin{array}{c}\text { Jurnal } \\
\text { Akuntansi }\end{array}$ & $\begin{array}{l}\text { Tren Penghindaran Pajak Perusahaan Manufaktur di Indonesia } \\
\text { yang Terdaftar di BEI Tahun 2001-2014 }\end{array}$ & 2 \\
\hline 30 & Siringoringo (2015) & $\begin{array}{l}\text { Jurnal } \\
\text { Akuntansi }\end{array}$ & $\begin{array}{l}\text { Pengaruh Penerapan Good Governance dan Whistleblowing } \\
\text { System terhadap Kepatuhan Wajib Pajak Orang Pribadi dengan } \\
\text { Resiko Sanksi Pajak sebagai Variabel Moderating Studi Empiris } \\
\text { terhadap Wajib Pajak Orang Pribadi di Kota Bekasi }\end{array}$ & 2 \\
\hline
\end{tabular}




\begin{tabular}{|c|c|c|c|c|}
\hline $\begin{array}{l}\text { Rangking } \\
\text { berdasarkan } \\
\text { Jumlah Sitasi }\end{array}$ & Penulis & Jurnal & Judul & Sitasi \\
\hline 31 & Diamastuti (2016) & EKUITAS & Ke(tidak)patuhan Wajib Pajak: Potret Self Assessment System & 1 \\
\hline 32 & Syanthi dkk (2013) & EKUITAS & $\begin{array}{l}\text { Dampak Manajemen Laba terhadap Perencanaan Pajak dan } \\
\text { Persistensi Laba }\end{array}$ & 1 \\
\hline 33 & $\begin{array}{l}\text { Rachmawati \& Martani } \\
\text { (2014) }\end{array}$ & JAKI & $\begin{array}{l}\text { Pengaruh Large Positive Abnormal Book-Tax Differences } \\
\text { terhadap Persistensi Laba }\end{array}$ & 1 \\
\hline 34 & $\begin{array}{l}\text { Darmayasa \& Aneswari } \\
(2016)\end{array}$ & JAMAL & The Role of Local Wisdom to Tax Compliance & 1 \\
\hline 35 & Sugiono dkk (2015) & JAMAL & Makna Pajak dan Retribusi Perspektif Wajib Pajak Kaki Lima & 1 \\
\hline 36 & Fasmi \& Misra (2014) & JAMAL & $\begin{array}{l}\text { Modernisasi Sistem Administrasi Perpajakan dan Tingkat } \\
\text { Kepatuhan Pengusaha Kena Pajak }\end{array}$ & 1 \\
\hline 37 & $\begin{array}{l}\text { Ratnafuri \& Herawati } \\
(2012)\end{array}$ & JAMAL & $\begin{array}{l}\text { Malpraktek Pemotongan dan Pemunggutan Pajak oleh } \\
\text { Bendaharawan Pemerintah }\end{array}$ & 1 \\
\hline 38 & $\begin{array}{l}\text { Kartikasari \& Lasmana } \\
\text { (2013) }\end{array}$ & JAK & $\begin{array}{l}\text { Pengaruh Kebijakan Dividen terhadap Kepemilikan Indvidual } \\
\text { dan Kepemilikan Institusional dengan Perubahan Peraturan } \\
\text { Perpajakan sebagai Variabel Pemoderasi }\end{array}$ & 1 \\
\hline 39 & Sadjiarto (2008) & JAK & $\begin{array}{l}\text { Variasi Penghitungan dan Penyetoran Pajak Penghasilan Pasal } \\
21\end{array}$ & 1 \\
\hline 40 & Mangoting (2003) & JAK & $\begin{array}{l}\text { Tinjauan Aspek Pajak Penghasilan atas Transaksi Instrumen } \\
\text { Keuangan Derivatif SWAP }\end{array}$ & 1 \\
\hline 41 & $\begin{array}{l}\text { Marfuah \& Azizah } \\
\text { (2014) }\end{array}$ & JAAI & $\begin{array}{l}\text { Pengaruh Pajak, Tunneling Incentive dan Exchange Rate pada } \\
\text { Keputusan Transfer Pricing Perusahaan }\end{array}$ & 1 \\
\hline 42 & $\begin{array}{l}\text { Setyaningsih \& } \\
\text { Okfitasari (2016) }\end{array}$ & EKUITAS & $\begin{array}{l}\text { Mengapa Wajib Pajak Mengikuti Tax Amnesti (Studi Kasus di } \\
\text { Solo) }\end{array}$ & 0 \\
\hline 43 & $\begin{array}{l}\text { Novita \& Hartadinata } \\
\text { (2016) }\end{array}$ & EKUITAS & $\begin{array}{l}\text { Pendidikan Perpajakan: Persepsi Akademisi, Praktisi, dan } \\
\text { Mahasiswa untuk Jenjang Diploma dan Sarjana }\end{array}$ & 0 \\
\hline 44 & $\begin{array}{l}\text { Sudaryono \& Setiawan } \\
(2015)\end{array}$ & EKUITAS & $\begin{array}{l}\text { Manajemen Laba dan Penerapan UU No. 36/2008 tentang } \\
\text { Perubahan Penghitungan Pajak Penghasilan }\end{array}$ & 0 \\
\hline 45 & Hamzah (2011) & EKUITAS & $\begin{array}{l}\text { Daya Prediksi Pajak, Laba dan Arus Kas terhadap Pajak Masa } \\
\text { Depan pada Perusahaan Manufaktur di Bursa Efek Indonesia }\end{array}$ & 0 \\
\hline 46 & $\begin{array}{l}\text { Soedjono \& Handayani } \\
(2005)\end{array}$ & EKUITAS & $\begin{array}{l}\text { Efektifitas Pelaksanaan Peraturan Daerah tentang } \\
\text { Retribusi/Iuran Pasar Daerah di Kota Surabaya }\end{array}$ & 0 \\
\hline 47 & Ngumar (2000a) & EKUITAS & Penerapan Akuntansi Perpajakan di Indonesia & 0 \\
\hline 48 & Ngumar (2000b) & EKUITAS & Peranan Akuntansi dalam Perpajakan di Indonesia & 0 \\
\hline 49 & Ngumar (2000c) & EKUITAS & $\begin{array}{l}\text { Tax Planning untuk Pembayaran Pajak dengan Benar bagi } \\
\text { Perusahaan di Indonesia }\end{array}$ & 0 \\
\hline 50 & Suryono \& Anita (1998) & EKUITAS & $\begin{array}{l}\text { Tingkat Pemahaman Wajib Pajak terhadap Undang-Undang No. } \\
\text { 10/1994 }\end{array}$ & 0 \\
\hline 51 & Riduwan (1998) & EKUITAS & $\begin{array}{l}\text { Akuntansi Pajak Penghasilan (Pernyataan Standar Akuntansi } \\
\text { Keuangan No. 46) }\end{array}$ & 0 \\
\hline 52 & Herlambang (1997) & EKUITAS & $\begin{array}{l}\text { Making Social Welfair Through National Tax System Efficiency } \\
\text { in Indonesia }\end{array}$ & 0 \\
\hline 53 & Retnani (1997) & EKUITAS & Penerapan Akuntansi Perpajakan di Indonesia & 0 \\
\hline 54 & Geraldina (2013) & JAKI & $\begin{array}{l}\text { Preferensi Manajemen Laba Akrual atau Manajemen Laba Riil } \\
\text { dalam Aktivitas Tax Shelter }\end{array}$ & 0 \\
\hline 55 & Irreza \& Yulianti (2012) & JAKI & $\begin{array}{l}\text { Penggunaan Komponen Pembentuk Pajak Tangguhan dalam } \\
\text { Mendeteksi Manajemen Laba }\end{array}$ & 0 \\
\hline 56 & $\begin{array}{l}\text { Nuryanah \& Christine } \\
\text { (2009) }\end{array}$ & JAKI & $\begin{array}{l}\text { Income Tax Gap: Kajian Deskriptif dan Empiris atas Koreksi } \\
\text { Pajak di Indonesia }\end{array}$ & 0 \\
\hline 57 & Yulianti (2005) & JAKI & $\begin{array}{l}\text { Kemampuan Beban Pajak Tangguhan dalam Mendeteksi } \\
\text { Manajemen Laba }\end{array}$ & 0 \\
\hline 58 & Prasetyo (2016) & JAMAL & $\begin{array}{l}\text { Menjamin Kepatuhan Wajib Pajak melalui Penerbitan Surat } \\
\text { Tagihan Pajak }\end{array}$ & 0 \\
\hline 59 & $\begin{array}{l}\text { Rusydi \& Djakman } \\
\text { (2016) }\end{array}$ & JAMAL & Pengaruh Book-Tax Differences terhadap Investor Trading & 0 \\
\hline 60 & Yuhertiana dkk (2016) & JAMAL & Etika, Organisasi dan Kepatuhan Wajib Pajak & 0 \\
\hline 61 & Sari \& Lyana (2015) & JAMAL & Book Tax Differences dan Kualitas Laba & 0 \\
\hline 62 & Mutiah dkk (2011) & JAMAL & $\begin{array}{l}\text { Interpretasi Pajak dan Implikasinya Menurut Perspektif Wajib } \\
\text { Pajak Usaha Mikro, Kecil dan Menengah }\end{array}$ & 0 \\
\hline 63 & $\begin{array}{l}\text { Sumiyana \& Pribadi } \\
(2010)\end{array}$ & JAMAL & $\begin{array}{l}\text { Keberterimaan Situs Pajak: Pengindustrian Orientasi Tujuan } \\
\text { Pembelajaran dan Norma Subjektif }\end{array}$ & 0 \\
\hline 64 & Rusydi (2010) & JAMAL & $\begin{array}{l}\text { Analisis Pengaruh Perubahan Peraturan Perpajakan pada } \\
\text { Sektor Usaha Jasa Konstruksi di Indonesia }\end{array}$ & 0 \\
\hline 65 & Tjondro dkk (2016) & JAK & $\begin{array}{l}\text { Kualitas Corporate Social Responsibility dan Penghindaran } \\
\text { Pajak dengan Kinerja Laba sebagai Moderator }\end{array}$ & 0 \\
\hline 66 & Mangoting (2008) & JAK & Mengapa Perlu Menghapus SPT Tahunan 1721? & 0 \\
\hline 67 & Ibrahim dkk (2003) & JAK & $\begin{array}{l}\text { Manajemen Pendapatan dan Pengecualian Pajak Pendapatan di } \\
\text { Malaysia* }\end{array}$ & 0 \\
\hline 68 & Mangoting (2000b) & JAK & Menyongsong Tax Reform 2001: Khusus Pajak Penghasilan & 0 \\
\hline
\end{tabular}




\begin{tabular}{|c|c|c|c|c|}
\hline $\begin{array}{c}\text { Rangking } \\
\text { berdasarkan } \\
\text { Jumlah Sitasi }\end{array}$ & Penulis & Jurnal & Judul & Sitasi \\
\hline 69 & Saputra dkk (2015) & JAAI & $\begin{array}{l}\text { Pengaruh Corporate Governance, Profitabilitas dan Karakter } \\
\text { Eksekutif terhadap Tax Avoidance pada Perusahaan yang } \\
\text { Terdaftar di BEI }\end{array}$ & 0 \\
\hline 70 & Ratmono (2014) & JAAI & $\begin{array}{l}\text { Model Kepatuhan Perpajakan Sukarela: Peran Denda, Keadilan } \\
\text { Prosedural, dan Kepercayaan terhadap Otoritas Pajak }\end{array}$ & 0 \\
\hline 71 & $\begin{array}{l}\text { Tarjo \& Kusumawati } \\
\text { (2010) }\end{array}$ & JAAI & $\begin{array}{l}\text { Analisis Perilaku Wajib Pajak Orang Pribadi terhadap } \\
\text { Pelaksanaan Self Assessment System: Suatu Studi di Bangkalan }\end{array}$ & 0 \\
\hline 72 & $\begin{array}{l}\text { Hanna \& Haryanto } \\
(2016)\end{array}$ & $\begin{array}{c}\text { Jurnal } \\
\text { Akuntansi }\end{array}$ & $\begin{array}{l}\text { Agresivitas Pelaporan Keuangan, Agresivitas Pajak, Tata Kelola } \\
\text { Perusahaan dan Kepemilikan Keluarga }\end{array}$ & 0 \\
\hline 73 & $\begin{array}{l}\text { Harnovinsah \& } \\
\text { Mubarakah (2016) }\end{array}$ & $\begin{array}{c}\text { Jurnal } \\
\text { Akuntansi }\end{array}$ & Dampak Accounting Choices terhadap Tax Aggressive & 0 \\
\hline 74 & Amilin (2016) & $\begin{array}{c}\text { Jurnal } \\
\text { Akuntansi }\end{array}$ & $\begin{array}{l}\text { Peran Konseling, Pengawan dan Pemeriksaan oleh Petugas } \\
\text { Pajak dalam Mendorong Kepatuhan Wajib Pajak dan } \\
\text { Dampaknya terhadap Penerimaan Negara }\end{array}$ & 0 \\
\hline 75 & Salsabila dkk (2016) & $\begin{array}{c}\text { Jurnal } \\
\text { Akuntansi }\end{array}$ & $\begin{array}{l}\text { Pengaruh Book Tax Differences dan Aliran Kas Operasi terhadap } \\
\text { Persistensi Laba }\end{array}$ & 0 \\
\hline 76 & $\begin{array}{l}\text { Indrawati \& } \\
\text { Budiwitaksono (2015) }\end{array}$ & $\begin{array}{c}\text { Jurnal } \\
\text { Akuntansi }\end{array}$ & $\begin{array}{l}\text { Studi Faktor-Faktor Pemotivasi Manajemen Melakukan Tax } \\
\text { Planning }\end{array}$ & 0 \\
\hline 77 & Tiaras \& Wijaya (2015) & $\begin{array}{l}\text { Jurnal } \\
\text { Akuntansi }\end{array}$ & $\begin{array}{l}\text { Pengaruh Likuiditas, Leverage, Manajemen Laba, Komisaris } \\
\text { Independen dan Ukuran Perusahaan terhadap Agresivitas Pajak }\end{array}$ & 0 \\
\hline 78 & $\begin{array}{l}\text { Iskandar \& Haryanto } \\
\text { (2015) }\end{array}$ & $\begin{array}{c}\text { Jurnal } \\
\text { Akuntansi }\end{array}$ & $\begin{array}{l}\text { The Influence of Implicit Tax in Making Profitable Foreign Direct } \\
\text { Investment Decisions: Evidence of Indonesian Listed Companies } \\
\text { in All Sectors }\end{array}$ & 0 \\
\hline 79 & $\begin{array}{l}\text { Chandra \& Hanna } \\
\text { (2015) }\end{array}$ & $\begin{array}{c}\text { Jurnal } \\
\text { Akuntansi }\end{array}$ & $\begin{array}{l}\text { Pengaruh Manajemen Laba dan Perbedaan Pembukuan } \\
\text { Menurut Pajak dan Akuntansi terhadap Peringkat Obligasi }\end{array}$ & 0 \\
\hline 80 & Riduwan (1997) & EKUITAS & $\begin{array}{l}\text { Akuntansi Pajak Pertambahan Nilai dan Pajak Penjualan } \\
\text { Barang Mewah }\end{array}$ & - \\
\hline 81 & Lasmana dkk (2005) & JAKI & $\begin{array}{l}\text { Pengaruh Penerapan Sistem Monitorung Pelaporan } \\
\text { Pembayaran Pajak (MP3) terhadap Tingkat Kepatuhan Wajib } \\
\text { Pajak (Studi Empiris pada Kantor Wilayah Direktorat Jenderal } \\
\text { Pajak Jawa Bagian Timur I) }\end{array}$ & - \\
\hline 82 & Kariyoto dkk (2012) & JAMAL & $\begin{array}{l}\text { Pengaruh Kesadaran dan Kepatuhan Wajib Pajak terhadap } \\
\text { Kinerja Perpajakan (Studi pada Kanwil Ditjen Pajak Jawa } \\
\text { Timur III) }\end{array}$ & - \\
\hline 83 & Salman \& Farid (2010) & Ventura & $\begin{array}{l}\text { Study of The Taxpayers Compliance in Banking Industries in } \\
\text { Surabaya }\end{array}$ & - \\
\hline
\end{tabular}

*4 penelitian dengan setting penelitian di Luar Indonesia 